\title{
NATURE AND EFFECTS OF CONSENT WITH RESPECT TO \\ THE RIGHT TO LIFE AND THE RIGHT TO PHYSICAL AND MENTAL INTEGRITY IN THE MEDICAL FIELD: CRIMINAL AND PRIVATE LAW ASPECTS*
}

\author{
J.-G. CASTEL**
}

\section{INTRODUCTION}

The purpose of this article is to analyze the nature and effects of a patient's or subject's consent to therapeutic and non-therapeutic treatment and research in Canadian criminal law, and in the private law of Quebec and the common law provinces, and to propose guidelines for possible legislation.

The effect of the victim's consent to an illicit act is the basic question. The scope of this inquiry is both general and particular, since it covers general principles concerning the effect of the victim's consent to an act which is illicit under Canadian criminal law or private law and the application of these principles in the case of an individual's right to life and physical and mental integrity with respect to treatment and experiments of a therapeutic and non-therapeutic nature.

The article is divided into three parts. Part I deals with a definition of consent, an analysis of its elements, especially the notion of "informed" consent, and its effects on the crimininal law and private law in general. Part II is devoted to the rights to life and physical and mental integrity. Here, the general principles are applied specifically to therapeutic and non-therapeutic treatment and research. Part III contains some conclusions as well as some proposals for reform.

\section{GENERAL PRINCIPLES}

\section{(A) Nature of Some of the Questions to be Analyzed}

The effect of the victim's consent upon a criminal or private offence is a question which arises quite often, especially in the medical field. Is the victim's consent a justification for a criminal or tortious (or delictual) act or omission that has caused him injury? Should the victim's consent be effective with respect to all types of illicit acts or omissions?

When an act or omission is punished by the penal law, it means that this act or omission is of concern to the State, or to society in general, in other words, it is against public policy. Should the victim's consent justify or excuse such act or omission and make it licit as, for instance, in the case of self-defense? This raises the question whether in Canada the Roman maxim volenti non fit injuria is a general principle of the criminal as well as of the private law. This does not appear to be the case in the criminal law as, historically, the maxim was only applicable to the private delict or tort called "injuria"1 which involved the infringement of private rights that could be waived by the victim.

The victim's consent is not a general principle to be found in the Canadian Criminal Code although it is mentioned in several sections of

- This article is based on a study prepared for the Canada Law Reform Commission. The views expressed here do not represent in any way those of the Commission.

-* of Osgoode Hall Law School, Toronto.

1. Digest, Book XLVII, Tit. 10, Law 1, 5. 
the Code. ${ }^{2}$ The private law in force in the common law provinces is also silent on the question although resort is had to the maxim volenti non fit injuria. In Quebec, however, the Civil Code contains provisions dealing with some aspects of consent. ${ }^{3}$

Quite often society is confronted with cases where the victim has consented to illicit acts which may have caused him some irreparable injury at least in an objective sense. For instance, a husband, at the request of his wife who is dying of an incurable disease, shortens her life. A person gives some blood to the Red Cross, or requests an operation to improve his or her looks, or gives a kidney to his brother or sister. Objectively speaking, these acts may amount to homicide or assault. Yet should the victim's consent excuse the husband, nurse or surgeon performing such an illicit act?

To what extent does the victim's consent affect the application of the criminal or private law? Should every illicit act sanctioned by the Criminal Code be deemed against the public policy of the State so that the victim's consent to it would be no valid excuse or justification?

\section{(B) Definitions and Legal Nature of Consent}

\section{Definitions}

Several definitions of consent may be given. For instance, Glanville Williams has defined consent in layman's terms in the following manner:4

[C]onsent is the opposite of objection; it includes states of mind ranging from eager desire at the one extreme to passive and reluctant acquiescence at the other. . .. In general it may be said that if an adult has an opportunity to oppose an act done in respect of him, and if with knowledge of the facts he decides not to oppose it-certainly if he positively desires it-he consents to it.

The Oxford English Dictionary also defines consent in layman's terms as a "voluntary agreement to or acquiesence in what another proposes or desires; compliance, concurrence, permission". However, the law has superimposed its own stipulations as to what amounts to consent in law, who can give a legally recognized consent and what can validly be consented to.

Fahmy Abdou ${ }^{6}$ defines consent as the permission given by a private individual ${ }^{7}$ to one or more persons to do an act of a private nature that is forbidden by the positive penal or private law, or to abstain from doing an act of a private nature that is required by the positive penal or private law which infringes or takes away a right (personal right or property right) protected by law which belongs to the person who gives such permission.

Prima facie, it seems difficult to accept the view that since illicit acts are defined by the legislator, a private individual can exempt another from the application of the criminal or private law. Where public policy is involved, it cannot be disregarded. No individual should be able to render licit that which is intrinsically illicit. When the social order is at stake, the offender must be punished even if the victim absolved him. To give

\footnotetext{
2. E.B., Criminal Code, 88. 14, 143, 244 discussed infra.

3. Civ. C., arts. 19 to $22,984,988,991-1000$, and see infra.

4. Criminal Law (2nd ed, 1961) 772.

5. (1971). The word derives from the latin cum "with" and sentire "to feel" or "to think".

6. Le consentement de la victime (1971), 35.

7. A public official cannot consent to an illicit act being committed against the State although the State or one of its representatives may sive such a consent as a private person. This view is based upon the distinction between acta jure gestionis and acta jure imperii.
} 
some effect to consent, it must be understood that each illicit act violates a private as well as a public interest, the latter, a subjective State right. When this is the case, the victim cannot exonerate the offender. However, where the State's interest is solely to protect the victim, consent should be effective as such interest in upholding the law is only indirect. Where the State's interest is direct, the victim's consent is immaterial as the illicit act also violates a fundamental right of the State.

2. Self-inflicted Injury-Pactum ne dolus praestetur-

\section{Exculpatory Clauses}

It should be noted that the victim's consent differs from self-inflicted injury or death (auto-lésion) which is not punishable and the pactum ne dolus praestetur or exculpatory clause as in certain cases the legislator may wish to protect a person against his own wishes. ${ }^{8}$ The reason why self-inflicted death or injury is not punished in many countries is based on the view that a person cannot be both the active and passive subject of the offence. The victim cannot enjoy the right to life and be obligated by such right. In other words an individual does not have legal obligations towards himself. He cannot be at the same time the offender and the victim.

In the case of mayhem or an attempt to commit suicide, the State may have a direct interest in protecting the victim although, in Canada, attempted suicide is no longer an offence. ${ }^{9}$

The pactum ne dolus praestetur or exculpatory clause is an agreement between one or more persons prior to an intentional wrongful or illicit act whereby the offender will be exonerated from civil or criminal liability or both. In many countries such an agreement is against public policy and void. If consent and the pactum were the same, the victim's consent could never be a valid defence.

In the case of consent, an individual permits an act which is illicit. Thus, the unlawful character of the act is erased. The pactum does not erase the illicit character of the act. It is, rather, an anticipated pardon for an illicit act to which the victim may not necessarily wish to be subjected, whereas in the case of consent, the victim wishes the act or omission to act to take place. Therefore, one must examine the substantial contents of the victim's intention in order to determine whether it is a case of consent that may be valid or a pactum which is void. To recognize the validity of the pactum would incite individuals to commit offences. In the case of consent, the injury or damage is no longer illicit whereas in the case of a pactum it is still illicit because it encourages violation of the law which is against public policy, thus rendering the injury illicit.

\section{Legal Nature}

It is possible to assert that the victim's consent means that he is renouncing in advance (a) his right to damages (private law aspect), or (b) his right to lay an information or charge against the actor (criminal law aspect), or both. However, since the victim's consent, when admitted, renders that act licit, he cannot renounce a right that will never come into existence. Furthermore, such a renunciation would be a pactum ne dolus praestetur which may be illicit and void.

8. For instance in Canada, suicide which is self-inflicted death is not punishable but homicide on demand or counselling or aiding suicide is: Criminal Code, 88. 14, 224.

9. See Criminal Code, B. 225 repealed in 1972. 
Consent could also be considered as the transfer of the exercise of a right by its beneficiary to another person, or a legal act of authorization which is individualized, autonomous and of a material nature. These various approaches seem to make it clear that the victim's consent is a special autonomous type of legal obligation which must follow special rules.

Personal or property rights are protected in different ways by the penal law and the private law. Some rights are protected only so long as the persons entitled to enjoy them do not allow them to be infringed or destroyed. They are rights that may be disposed of or waived ("disponibles") very freely. Other rights are protected by law even against the wishes of the persons entitled to enjoy them. They cannot be disposed of or waived ("indisponibles"). Consent should be effective only with respect to rights that may be disposed of or waived. Public policy determines the nature of such rights.

To conclude, it would appear that the victim's consent consists in the faculty recognized by the criminal law or the private law to the beneficiary of a personal or property right to suspend vis à vis one or more persons, the efficacy of a legal provision protecting this right. Since the person entitled to enjoy a right or to infringe or destroy such a right (consenting person) may give to another person (the recipient of consent) permission to infringe or destroy such a right, consent should always be revocable. In this sense consent is a unilateral act.

All penal rules are not necessarily imperative. The application of the criminal law may, in some cases, depend upon the wishes of the victim. Sometimes the Criminal Code incorporates the requirement of absence of consent into the definition of the offence; ${ }^{10}$ sometimes the absence of consent is implied in the offence although it is not expressly mentioned in the text. Thus, the victim's consent is not always contrary to the imperative and obligatory nature of the legal rule.

Rights are not always protected against the wishes of those entitled to enjoy them unless they are of general interest to the State and society. In each society there exists a hierarchy in the protection of rights which depends upon their social importance and the degree to which their violation infringes public order. Some are protected against those who are entitled to enjoy them, others only in so far as their beneficiaries do not consent to such rights being infringed. In private law cases and in some criminal cases, the application of the rules may depend upon the wishes of an individual person, since the victim must bring the action or lay an information. If the victim does not complain, a legal action may not always be possible.

\section{(C) Elements of Consent: "Informed" Consent}

Since the victim's consent is essentially a unilateral juridical act with some bilateral aspects, it is subject to the general rules applicable to juridical acts in the common law provinces and in the civil law of Quebec.11 However, consent also differs from other juridical acts, such as contracts, as it has a special function to perform.

10. See infra.

11. Consent, in a strict sense, is a unilateral juridical act but "informed" consent within the medical context has bilateral aspects since the physician may have a duty to inform the patient objectively, and even perhaps subjectively, a duty to ensure that the patient understands, and a duty to continue to inform. See discussion infra. It is not intended to review the common law and civil law rules pertaining to consent in the contractual field. In Quebec, see Baudouin, Les Obligations (1970), s8. 71 et seq. 


\section{Forms of Consent}

It is well established in all legal systems that consent must be exteriorized to have any effect. However, a formal declaration is not necessary. A simple manifestation of the victim's intention is sufficient. Thus, consent may be oral or written, express or implied. ${ }^{12}$ Silence is consent only if, objectively, it can be interpreted as a manifestation of the will of the consenting person. Simple toleration is not necessarily consent.

Consent may be reluctantly given. This is important in the medical field where consent must be "informed". Consent may also be presumed. The presumption must be reasonable (as, for instance, in the case of emergency operations), and reasonableness depends upon the circumstances. Consent must also be certain.

\section{Formalities}

No special formalities are required to express a valid consent. However, where a person consents to disposal inter vivos of a part of his body or submits to an experiment, the consent of such person (or in the case of a minor capable of discernment, of those who are authorized by law to consent on his behalf) must be in writing. ${ }^{13}$ This may also be the case with respect to consent to surgery, anaesthetics, or a diagnostic test. ${ }^{14}$

\section{Conditions of Validity}

Consent must validly be given. The general principles of the common law and of the civil law of Quebec are applicable. However, in the criminal law field it is suggested that the civil law or common law distinction between an act that is void and one that is voidable (nullité relative ou absolue) should not prevail. Thus, an illicit act should not be subject to retroactive ratification. Consent which infringed or destroyed the right protected by law, must have existed at the time the act was performed; to hold otherwise would be contrary to the essence of the criminal law. Furthermore, from a juridical point of view, the victim's consent would amount to a private pardon which is not legally recognized.

\section{Vices of Consent}

In the private law field, consent must not have been vitiated by error, fraud, violence or fear ${ }^{15}$ especially moral violence, as for instance in the case of a reluctant donor of a kidney transplant. In other words, consent must be freely given.

In the criminal law field, consent must be freely given and not extorted.16 The Criminal Code when dealing with sexual acts done in private between consenting adults, provides in section 158 that:

158 (2) (b) a person shall be deemed not to consent to the commission of an act (i) if the consent is extorted by force, threats or fear of bodily harm or is obtained by false and fraudulent misrepresentations as to the nature and quality of the act, or . . .

12. Que. Civ. C., art. 988. Consent may be implied from facts which could not be explained in its absence. Baudouin, id., ss. 72 et seq.

13. E.g., Que. Civ. C., art 20, Ontario Human Tissue Gift Act, 1971, S.O., 1971, c. 83, s. 3. Similar provisions exist in other provinces.

14. See e.g., Quebec, regulation under the Health Services and Social Services Act, L.Q., 1971, c. 48, G.O.Q. Nov. 25,1972 , vol. 104, no. 47, p. 10566, at pp. 10574 et seq, arts 3.2.3.1 and 3.2.1.11. Ontario regulations under the Public Hospitals Act, R.S.O. 1970, c. 378, as am., R.R.O. 1970, Reg. 729, 8s. 49, 49a.

15. See, e.g., Que. Civ. C., arts. 991-1000 dealing with the law of obligations.

16. See Perkins, Criminal Law 963-4 (2nd ed., 169); Smith and Hogan, Criminal Law 287 (3rd ed., 1973); Russell on Crime 678 (12th ed., 1964). 
This provision could be applied in other situations.

Therefore, consent under duress is no consent at all. Nor is mere submission consent. ${ }^{17}$ Fraud, however, negatives consent only if it deceives the consenting person as to the identity of the accused or the nature of the act. ${ }^{18}$ As stated per Hartt J. in $R$. v. Maurantonio: ${ }^{19}$

... The general rule is that if deception causes a misunderstanding as to the nature of the act itself there is no legally recognized consent because what happened is not that for which consent was given, whereas consent induced by fraud is as effective as any other consent if the deceit relates not to the thing done but merely to some collateral matter.

Section 145 of the Criminal Code clearly states that it is rape when a woman consents to sexual intercourse because the man impersonated her husband. In the famous case of The Queen v. Clarence, ${ }^{20}$ a woman had sexual intercourse with her husband who knew he was suffering from gonorrhoea. The wife, who subsequently contracted the disease, claimed that her consent had been obtained by fraud since she certainly would not have consented had she known of her husband's condition. The husband was charged with assault causing bodily harm but while the court agreed that the conduct of $\mathrm{Mr}$. Clarence left something to be desired, it nevertheless held that his wife's consent had been valid since she was not deceived as to the nature of the act itself, that is, sexual intercourse:21

It seems to me that the proposition that fraud vitiates consent in criminal matters is not true if taken to apply in the fullest sense of the word, and without a qualification. . . . If we apply it in that sense to the present case, it is difficult to say that the prisoner was not guilty of rape, for the definition of rape is having connection with a woman without her consent; and if fraud vitiates consent, every case in which a man infects a woman or commits bigamy, the second wife being ignorant of the first marriage, is also a case of rape.

.. The woman's consent here was as full and conscious as consent could be. It was not obtained by any fraud either as to the nature of the act or as to the identity of the agent. The injury done was done by a suppression of the truth. It appears to me to be an abuse of language to describe such an act as an assault.

\section{5. "Informed" Consent}

In the medical field, for consent to be valid and effective, it must be "informed". In civil law jurisdictions, this may be considered as an application of the general principle that consent is of no effect when a mistake or an error is the principal reason for consenting. ${ }^{22}$ The difficulty lies in the determination of the quality of the mistake or error that renders a person's consent invalid in any factual situation.

In the common law provinces, "informed" consent, where no mistake or error in consenting has taken place, pertains more to the preservation of the physical integrity and personal liberty of the patient than the absolution of the physician. Actually, mistake or error is usually not involved in "informed" consent as a principal reason for consenting. It is the non-disclosure which may or may not have caused the patient to consent. The emphasis is not on the mistake or error of the patient

17. Perkins, id. at 711; Smith and Hogan, id. at 287; Russell, id. at 109.

18. Smith and Hogan, id. at 287. For a discussion of the effect of fraud on consent in American jurisprudence, see Perkins, id. at 964-969.

19. (1967), 65 D.L.R. (2d) 674 at 681 (Ont. C.A.); see also, Bolduc and Bird v. The Queen (1967), 63 D.L.R. (2d) 82 (S.C.C.).

20. (1886), 22 Q.B.D. 23.

21. Id., per Stephen J., at 43-44.

22. A distinction must be made between consent to the patient-physician relationship and consent to treatment. The evidence of the former does not necessarily imply the existence of the latter. 
although he may have misunderstood the information given to him, but on the negligence of the physician in not disclosing, and whether this caused the damage to the patient. Where there is a duty to disclose, lack of disclosure vitiates the patient's consent.

The common and the civil law also appear to differ significantly in their tests of causation. In Kelly v. Hazlett ${ }^{23}$ the Ontario court clearly expressed the view that in the context of a claim based on negligence, it must be determined whether the physician had a duty to disclose definitive as well as collateral risks inherent in any proposed surgical procedure. The proper scope of the disclosure depends upon the circumstances. As to causation, the patient must satisfy the court that if he had been properly informed of the risk involved in the surgical procedure and had been made to understand it, he would have foregone such procedure and hence not suffered the alleged damage.

In Canada, there are no general legislative provisions dealing with "informed" consent. However, the Civil Code of Quebec states in article 20 that:

A person of full age may consent in writing to disposal inter vivos of a part of his body or submit to an experiment provided that the risk assumed is not disproportionate to the henefit anticipated.

A minor, capable of discernment, may do likewise with the consent of . . . provided that no serious risk to his health results therefrom. . . .

The words italicized seem to indicate that before a patient or subject's consent can be validly obtained, there is a duty to disclose or to inform whether or not there is a serious risk to the health of the patient or subject. This gives legislative support to the doctrine of "informed" consent in this area of human activities. The Ontario Human Tissue Gift Act 1971, also speaks of a person able to make "a free and informed decision". ${ }^{24}$ It is submitted that the doctrine of "informed" consent should be applied by the courts in all instances where the victim's consent is a relevant consideration. Of course the type of information to be given should vary depending upon the circumstances in which consent is given.

There are no set rules as to the requirements of "informed" consent, also called legally "effective" consent. The courts in Canada, the United States and England are not always in agreement on this question. It seems quite obvious that "informed" consent should be viewed not as a single act but as a process of contracting, negotiating, and recontracting. Informed consent, which involves comprehension of adequate information and autonomy of consent, is a continuing process throughout the treatment or experiment. In the medical field, sufficient information must be disclosed to the patient so that he can arrive at an intelligent opinion, and the patient must agree to the intervention being performed.

By promoting trust and confidence between patient and physician, informed consent requirements may thus advance rational decision making. . . . The freedom to make decisions for oneself carries with it the obligation to answer for the consequences of those decisions. ${ }^{25}$

The literature on the subject of "informed" consent is immense. ${ }^{26}$ For the

23. (1976), 75 D.L.R. (3d) 536, 15 O.R. (2d) 290 (H.C.). See also, Mayrand, L'inviolabilité de la personne humaine (1975), 38.

24. Supra, n. 13, s. 3(1) and (2). There are other provisions dealing with the necessity of consent, see for instance, Ontario Regulation under the Public Hospital Act, R.R.O. 1970, Reg. 729, s. 49.

25. Capron, Informed Consent in Catastrophic Disease Research and Treatment, (1974), 123 U. of Pa. L. Rev. 340 at 365.

26. In Canada, see e.g., Dickens, Information for Consent in Human Experimentation (1974), $24 \mathrm{U}$. of T. L.J. 381; Rozovsky, Consent to Treatment (1973), 11 Osgoode Hall L.J. 103. 
purpose of this article, an attempt will be made to restrict the discussion to the essential points.

The courts have held that informed consent is a prerequisite to any act involving risk to a patient or subject except in certain emergencies. ${ }^{27}$ Thus, it seems that the physician has no automatic duty to inform every patient who visits him before obtaining his consent. For instance, when no treatment or experiment or special testing procedure is contemplated, the patient's implied consent should be sufficient to allow the physician to carry out a physical examination and to diagnose the patient's ailment. The duty to inform is a continuing one of changing contents. The physician cannot disclose all the risks of treatment at the examination stage because he may not know what these will be; however, when he does know, he must disclose them.

Furthermore, mention should be made of the so-called therapeutic privilege to withhold information. There is some information which the physician is not required to disclose, such as the risks of contracting serum hepatitis from blood transfusion. Information which would normally be given may also be withheld if it would be harmful or dysfunctional for a particular patient in his special circumstances. Finally, a patient should be given information of his prognosis if he remains untreated.

"Informed" consent with respect to therapeutic and non-therapeutic treatment or experiments involves:

1. Competence of the patient or subject. This raises the question of proxy consent in the case of minors or mentally incapable adults.

2. Knowledge of the definitive and collateral risks involved. ${ }^{28}$ Since in experimentation, by definition, some risks are unknown, it may be difficult to meet this requirement.

3. Voluntariness or autonomy of consent. The patient or subject must not be under covert or overt pressures, or under constraint ${ }^{29}$ or momentarily unable to consent. ${ }^{30}$

4. Freedom to withdraw consent and to discontinue participation in the treatment, project or activity at any time without prejudice to the consenting patient or subject.

The type of information that must be disclosed to the consenting patient or subject and comprehended by him comprises:

(a) A fair explanation of the procedures to be followed and their purposes, including identification of any procedures which are experimental.

(b) A description of any attendant discomforts and risks reasonably to be expected.

27. Slater v. Baker (1767), 95 E.R. 860 (K.B.); Kenny v. Lockwood, [1932] 1 D.L.R. 507 (Ont. C.A.); Mulloy v. Hop Sang. [1935] 1 W.W.R. 714 (Alta. App. Div.); Halushka v. The University of Saskatchewan (1965), 53.D.L.R. (2d) 436 (Sask. C.A.); Male v. Hopmans (1965), 54 D.L.R. (2d) 592 at 595, [1966] 1 O.R. 647 (H.C.), afrd (1967), 64 D.L.R. (2d) 105, [1967] 2 O.R. 457 (C.A.); Natanson v. Kline (1960), 186 Kan. 393, 350 P. 2 d 1093 rehearing denied 187 Kan. 186, 354 P. 2d 670; Hyman v. Jewish Chronic Disease Hospital (1964), 42 Misc. 2d 427, 248 N.Y.S. $2 d 245$ (Sup. Ct.), rev'd 21 App. Div. 2d 495, 251 N.Y.S. 2d 818, rev'd (1965), 15 N.Y. $2 d$ 317, 206 N.E. $2 d$ 338, 258 N.Y.S. 2d 397. Kelly v. Hazlett, supra, n. 23; Lepp v. Hopp (1977), 78 D.L.R. (3d), 35 (Ont. H.C.); Cryderman v. Ringrose, [1977] 3 W.W.R. 109 (Alta. D.C.); Reibl v. Hughes (1977), 78 D.L.R. (3d) 35, 16 O.R. (2d) 306 (Ont. H.C.). McLean v. Weir, Goff and Royal Inland Hospital, [1977] 5 W.W.R. 609 (B.C.S.C.) at 623-627.

28. Reibl v. Hughes, id.; Kelly v. Hazlett, supra, n. 23 at 564 (D.L.R.). A valid consent involves both awareness of the risk and assent to the procedure; see also Waltz, Scheuneman, Informed Consent to Therapy (1970), 64 Nw. U. L. Rev. 628.

29. Bowater v. Rowley Regis Corp., [1944] K.B. 476.

30. Beausoleil v. La Communauté des Soeurs de la Charité de la Providence (1964), 53 D.L.R. (2d) 65, [1965 ] Que. Q.B. 37 . 
(c) A description of any benefits reasonably to be expected.

(d) A disclosure of any appropriate alternative that might be advantageous for the patient or subject.

(e) An offer to answer any inquiries concerning the procedures.

(f) Comprehension by the patient or subject: Does the patient or subject understand what will be done to him, what risks he will face, and what benefits he or society may derive from the treatment or experiment?

"Informed" consent promotes individual autonomy, protects the patient or subject's status as a human being and reduces the likelihood of misleading or overbearing the patient or subject. It also encourages professional self scrutiny thereby avoiding thoughtless disrespect of patients or subjects and helps promote rational decision making. ${ }^{31}$

The amount of information that the physician must provide should vary according to the particular facts. This depends upon whether the treatment selected is a standard, well-established procedure involving minimal risks, or a procedure that is experimental involving greater ones. The riskier the procedure, the more complete must be the patient's or subject's knowledge and understanding. ${ }^{32}$ In such a case, there is a clear duty to inform and to obtain an express informed consent. The doctrine of implied consent arising from the physician-patient relationship is not sufficient.

In the field of medical research and experimentation the following guidelines have been proposed: ${ }^{34}$

The person giving consent must be informed fully of the nature and purpose of the research and of the procedures to be used, including identification of those procedures which are experimental, the possible attendant short or long term risks and discomforts, the anticipated benefits to himself and/or others, any alternative methods of treatment, expected duration of the study, and of his or her freedom to ask any questions and to withdraw at any time, should the person wish to do so. There must also be written evidence of the process used for obtaining informed consent, including grounds for belief that the subject has understood the information given and has sufficient maturity and mental capacity to make such choices and formulate the requisite judgment to consent. In addition, the person must have sufficient autonomy to choose, without duress, whether or not to participate. Both the comprehension of information and the autonomy of consent are necessary elements; to the extent that either of these is in doubt, the adequacy of informed consent may be in doubt.

These guidelines form part of the U.S. Code of Federal Regulations applicable to all Department of Health, Education and Welfare grants and contracts supporting research, development and related activities in which human subjects are involved:35

(c) 'Informed consent' means the knowing consent of an individual or his legally authorized representative, so situated as to be able to exercise free power of choice without undue inducement or any element of force, fraud, deceit, duress, or other form of constraint of coercion. The basic elements of information necessary to such consent include:

(1) A fair explanation of the procedures to be followed, and their purposes, including identification of any procedures which are experimental;

(2) A description of any attendant discomforts and risks reasonably to be expected;

(3) A description of any benefits reasonably to be expected;

31. See Capron, supra, n. 25 at 364-476: The Functions of Informed Consent. Kelly v. Hazlett, supra, n. 23 at 556 (D.L.R.).

32. Reibl v. Hughes, supra, n. 27.

34. U.S.A., Federal Register, Vol. 38, No. 221, Nov. 16, 1973, p. 31740 and 45 C.F.R. \& 46.3 (1974). See also Haluskha v. University of Saskatchewan and Cryderman v. Ringrose, supra, n. 27.

35. 45 C.F.R. Public Welfare $§ 46.102$ as of July 1, 1977. See also $\$ 46.110$. 
(4) A disclosure of any appropriate alternative procedures that might be advantageous for the subject;

(5) An offer to answer any inquiries concerning the procedures; and

(6) An instruction that the person is free to withdraw his consent and to discontinue participation in the project or activity at any time without prejudice to the subject.

In other words, information as to the nature, duration and purpose of the treatment and experiment must be given to the patient or subject before obtaining his consent. ${ }^{36}$

If informed consent is lacking, or the physician has exceeded the consent given by the patient, criminal or civil liability, or both may result unless the case falls within the provisions of sections 45 or 195 of the Criminal Code. ${ }^{37}$

Again it should be emphasized that the validity of the patient's or subject's consent can only be maintained by keeping his relevant information up to date over the entire duration of the treatment or experiment.

Unlike some American courts, Canadian courts have not attempted to lay down very strict criteria with respect to the elements of "informed" consent. Thus, a physician need not explain in detail the actual medical techniques to be used so long as the patient fully understands the nature of the treatment. 38 The courts seem to favour a subjective rather than an objective test in that the information to be given to the patient must depend upon his particular condition and mentality;39 to give the patient too much information may impair his recovery..$^{40}$ However, in the area of experimentation the courts will require stricter standards of disclosure. This approach should also be used in the case of non-experimental procedures.

In Kelly v. Hazlett Morden J. stated:42

I take it to be the law in this jurisdiction that the duty to disclose the collateral risk inherent in any proposed procedure is substantially a matter of medical judgment as opposed to being one of absolute and invariable content unlike the law in some United States jurisdictions where the duty is based upon the notion of what a reasonable patient might be expected to wish to hear in order to make up his mind and that, therefore, normally, the duty would be determined with the assistance of expert medical evidence on what would be the proper scope of disclosure in the circumstances presented. However, it has to be recognized that this test has both its practical and, perhaps, its policy frailties. In some cases it may be difficult to distinguish, and separate out, the matter of consequential or collateral risks from the basic nature and character of the operation or the procedure to be performed. This may possibly have been the case in Halushka v. University of Saskatchewan [(1965, 53 D.L.R. (2d) 436, 52 W.W.R. 608]. The more probable the risk the more it could be said to be an integral feature of the nature and character of the operation. Further, even if a risk is truly collateral, but still material, it could be said that its disclosure is so essential to an informed decision to undergo the operation that lack of such disclosure should vitiate the consent.

36. See also Nuremberg Code, U.S. v. Brandt, 2 Trials of War Criminals Before the Nuremberg Military Tribunals, 181-182; Declaration of Helsinki, 1964 as revised in 1975; American Medical Association Guidelines (1966); Medical Research Council of Canada, Ethics in Human Experimentation (1978).

37. As to emergencies see Marshall v. Curry, (1933] 3 D.L.R. 260 (N.S.S.C.). Note that the courts have gone quite far in extending the scope of consent in order to allow for the physician's exercise of judgment Caron v. Gagnon (1930), 68 Que. S.C. 155; $E$ v. $M$ (1939), 77 Que. S.C. 298; Bennett v. C. (1907-08), 7 W.L.R. 740 (Man.); Lafrénière v. Hopital Maisonneuve, [1963] Que. S.C. 467.

38. Johnston v. Wellesley Hospital, et al. (1970), 17 D.L.R. (3d) 139, [1971] 2 O.R. 103 (H.C.). See also Mayrand, supra, n. 23 at 38.

39. See Male v. Hopmans, supra, n. 27, (C.A.); Kenny v. Lockwood, supra, n. 27.

40. Male v. Hopmans, supra, n. 27. No remote warnings are necessary, McLean v. Weir et al., supra, n. 27 at 627.

41. See Halushka v. The University of Saskatchewan, supra, n. 27; Cryderman v. Ringrose, supra, n. 27.

42. Supra, n. 23 at 565 (D.L.R.). Also McLean v. Weir et al., supra, n. 27 at 627. 
To this, Haines J. added that “. . . it is not only the probability of a particular risk but the severity of its realized consequences which controls its characterization as an 'integral feature of the nature and character of the operation'. A description of the procedure without clear reference to those risks is misleading as to the nature and quality of the procedure; $a$ consent given in ignorance of that central and salient property of the surgery is no consent at all." 43

It might also be emphasized that "any doctrine of informed consent must take account of the limitations on patient-subjects' capacity to make intelligent and insightful choices. Some of these constraints are inherent in the intellectual faculties, psychological forces, and social pressures affecting the participants, while others result from personal, professional, and societal judgments about the scope of the authority which patientsubjects should be allowed to exercise".44

\section{Who May Consent}

The person entitled to the enjoyment of a right may consent to its infringement. However, he must be capable of consenting, and the informed consent must be freely given.

In the province of Quebec, as well as in the common law provinces, there are rules dealing with capacity to consent. As noted previously, article 20 of the Civil Code provides that a person of full age may consent to the disposal inter vivos of a part of his body or submit to an experiment. A minor, capable of discernment may do likewise with the consent of the person having the paternal authority and of a judge of the Superior Court. This rule is more restrictive than those prevailing with respect to other acts to be performed on behalf of minors or insane persons. 45

In Ontario, the Human Tissue Gift Act 1971, allows a person who has attained the age of majority and is mentally competent to consent to the removal from his body of the tissue specified in his consent. ${ }^{46}$ The Ontario Act does not recognize a consent given by a person who has not attained the age of majority or is not mentally competent, although in certain cases the physician may still be protected..$^{47}$ It is doubtful whether the courts would recognize a consent given by the parent or guardian or committee of a person who is a minor or insane when the procedure contemplated is of no benefit to the patient or subject. However, with respect to other matters, especially medical treatment, consent can be validly given by others on behalf of the minor or insane person ${ }^{48}$ or by the minor himself in certain circumstances. ${ }^{49}$

Section $158(b)(1)$ of the Criminal Code which deals with buggery, bestiality and acts of gross indecency committed in private between

43. Reibl v. Hughes, supra, n. 27 at 42 (D.L.R.). See also Lepp v. Hopp, supra, n. 27, where the court quoted Halushka to the effect that it is the duty of the physician to give a fair and reasonable explanation of the proposed treatment including the probable effect and any special or unusual risks.

44. Capron, supra, n. 25 at 376.

45. See Que. Civ. C., arts 290, 337, 349, 984-987.

46. Supra, n. 13, 8. 3. "Tissue includes an organ, but does not include any skin, bone, blood, blood constituent or other tissue that is replaceable by natural processes of repair." Similar legislation exists in other common law provinces.

47. See 8. 3(2).

48. But see Booth v. Toronto General Hospital (1910), 17 O.W.R. 118.

49. See Johnston v. Wellesley Hospital et al., supra, n. 34; R.R.O. 1970, Reg. 729, s. 49(c); Infants Act, R.S.B.C. 1960 , c. 193, s. 23; Uniform Medical Consent of Minors Act, 1975 Proceedings Uniform Law Conference of Canada 162 
husband and wife or consenting adults, provides that a person shall be deemed not to consent to the commission of such an act:

(ii) if that person is, and the other party to the commission of the act knows or has good reason to believe that that person is feeble-minded, insane, or an idiot or imbecile.

This subjective test should be extended to all criminal law offences where consent is relevant. At present, the test in other areas of the criminal law is an objective one since the consent of children and mental incompetents is no consent at all. ${ }^{50}$ Therefore, if a thirteen-year-old girl or a mentally retarded person consents to any sexual act with a man, her consent will not absolve him from criminal liability. ${ }^{51}$

It should be pointed out that a minor or insane person although incapable of giving a consent that is legally binding, may still express his natural will. Thus, in the medical field, it may be advisable to obtain the minor's consent in addition to that of his parent or guardian. While parental consent in the case of children approaching the age of majority may be a necessary condition of treatment, it may not be a sufficient condition.

An interesting question is whether a person legally capable of discernment, ${ }^{52}$ should be able to give a valid consent although he is not of age from the private law point of view. In other words, should capacity to consent be related to degrees of penal responsibility? The answer should be negative as criminal responsibility and legal capacity are two different matters. Capacity deals with the legal element of the offence; imputability refers to the responsibility of the alleged offender.

\section{The Recipient of Consent}

The recipient of consent need not be capable since consent is basically a unilateral juridical act. Therefore, he does not have to accept it or even know of its existence. However, where consent does not render the act licit but only diminishes criminal or civil responsibility its existence should be known to the person to whom it is given.

\section{Object, Consideration, or Cause of Consent}

The object of consent includes the act or omission and its effects. Such object must not be illicit or against public policy. For instance, it must not be contrary to an express provision of the law especially where consent to the act or omission is clearly prohibited as in the case of consent to homicide. ${ }^{53}$

This is also the case when the act is prohibited by law even if done by the person entitled to enjoy the right to be infringed, or where consent refers to some act or omission that is illicit although it is of such a nature that it requires the victim's consent. ${ }^{54}$ The consideration or cause for consenting must not be illicit.

\section{When Must Consent be Given?}

Consent must be given before the act or omission ${ }^{55}$ and must exist at the time of such an act or omission. Until then it can be revoked. As noted

50. Perkins on Criminal Law (2nd ed., 1969) 110.

51. See Criminal Code, 88. 140, 148.

52. Criminal Code, 8s. 12, 13.

53. Criminal Code, s. 14.

54. Note that the gale of tissue for a transplant or any body parts is prohibited. Que. Civ. C., art. 20 (unless it is susceptible of regeneration); Ontario Human Tissue Gift Act 1971, supra, n. 13, s. 10.

55. Glanville Williams, supra, n. 4 at 770. 
previously, consent cannot be given after the act and have a retroactive effect. It is at the time when the act was committed or the omission took place that the illicit character of the act must be ascertained. It cannot be made licit retroactively.

It is a question of fact whether consent was given with respect to a particular point in time, or before or after a particular point in time. If consent was given during the act or omission, it justifies only that part of the act or omission to act which took place after consent was given. This is important as in order to know whether or not an act or omission is an offence, one must consider all the surrounding circumstances at the time it took place.

When consent is given after the act or omission it is a pardon. It has nothing to do with the existence of the offence. However, consent after the act should be taken into consideration for the purpose of sentencing.

\section{Revocation of Consent}

Consent may always be revoked before or during the act or omission to act.

When by virtue of a contract, the person has agreed to give his consent and later revokes it, the act accomplished without consent is illicit although the recipient of the consent may be entitled to damages for breach of contract.

Revocation of consent may be expressed or implied. However, in the case of disposal inter vivos of a part of the body or submission to an experiment revocation must be in writing. ${ }^{56}$

\section{(D) Effects of Consent}

\section{General}

It may be argued that when consent is recognized by law as valid, it renders the forbidden act licit. Consent takes away the illicit character of the act which no longer violates the criminal law or the private law. The act consented to by the victim can be performed without the recipient of the consent committing a criminal offence or a civil wrong or both. ${ }^{57}$

The owner of the right is not injured legally although he may still be injured materially. Consent does not remove the subjective or moral element of the act but only its objective or legal element. It may also remove one of the essential elements of the offence.

Another view is that, depending upon the extent to which the victim's consent is effective, consent is a cause of justification, vis à vis an act which, without his consent, would be an illicit act.

Since the act consented to is no longer illicit, civilly or penally, no legal sanctions are in order. A civil or criminal action is not available to the injured party (the victim) or the State. Perhaps consent should have different effects depending upon the circumstances.

As a voluntary juridical fact, the victim's consent takes away the protection to which he is entitled and gives the recipient of the consent the right to do the act consented to. In other words, the victim's consent could be considered as a sort of legal title which would enable its recipient to infringe or destroy a right belonging to the person who gives the

57. Rather than consent rendering an illicit act licit, one could regard the act and consent operating as a sort of gestalt much like actus reus and mens rea, so that where there is the act and consent, the act is licit. 
consent. However, such a juridical fact is also a juridical act. It is an act which is penally and civilly important since it takes away the illicit character of the material fact (that is, the damaging act).

In the medical field it may be inadvisable to consider consent as a sort of legal title for the purpose of protecting a patient. It may be better to consider consent as a privilege within which the physician operates.

Finally, it is also essentially a unilateral act as it is the sole will of the consenting person which creates it and as a consequence makes licit the act which was done against him. However, in certain cases especially in the medical field, it has a bilateral aspect as the recipient of the consent must actively participate in obtaining an informed consent. This does not give it a consensual or contractual aspect, but only insures that the consent is validly given so as to protect the recipient of the consent.

\section{(a) The Limits of the Effect of Consent}

Penal law sanctions offences in the interest of society as well as in the interest of individuals. It is generally supportive of public order. The penal action is brought in the name of the Crown upon the laying of a public or private information. Once the action has begun, the victim's withdrawal from the case does not affect its prosecution (except in cases where the victim's complaint is the sole basis for the prosecution). Normally, the victim's consent has no effect on the action by the Crown. But does it have an effect on the elements of the offence itself, that is, on the very existence of the offence? If the victim's consent destroys the illicit character of the criminal act, can it be considered as a legal justification?

Consent does not erase the act but modifies its juridical nature. As noted above, consent renders licit an act which was illicit. The problem which faces the legislator and the courts is whether consent should be effective with respect to all legally protected rights.

It could be argued that there is no general principle of law in existence in Canada with respect to the limits of consent. Each case is sui generis depending upon the contents of the applicable law and the surrounding circumstances. However, what should be done when the law is silent?

\section{(b) Theories}

Several theories ${ }^{58}$ may be advanced with respect to the effect and scope of consent:

(1) Consent has no effect unless expressly provided by law.59 This theory is not necessarily correct as the law cannot foresee everything. When the legislator expressly provides for the effect of consent he has a special purpose. This does not mean that in other cases consent should have no effect.

(2) Consent is effective except where the legislator has decided otherwise. ${ }^{60}$ This theory is dangerous as it is too wide.

(3) Consent is effective only with respect to rights that can be waived or infringed. Some rights cannot be waived as for instance the right to life, the right to physical or mental integrity; others may be waived, as for instance, property rights. This theory may be too restrictive because consent should be effective with respect to some

58. For an analysis of these theories see Fahmy Abdou, n. 6 at 83 et seq.

59. As in Criminal Code, 8. 244.

60. As in Criminal Code, 8. 14. 
acts involving the physical or mental integrity of a person, for instance, the case of a surgical operation for the benefit of the patient.

(4) Consent is effective depending upon whether or not a person may be able to waive certain rights. This approach begs the question and is closely akin to the preceding theory.

(5) Consent is effective only in those cases where by law the prosecution of the alleged offender depends exclusively upon the victim's complaint. This view is too restrictive as in many legal systems the victim's complaint is not necessary.

(6) Consent is effective depending upon the motives of the person doing the act. Since suicide is not illicit, a person should be able to ask someone else to kill him provided the motive of the recipient of the consent is morally, legally and socially not reprehensible.61

The right must be one that can be waived. However, if this is the case, motive should be irrelevant. If the right cannot be waived, ${ }^{62}$ motive is equally irrelevant, although the responsibility of the recipient of the consent may be lessened and he may incur a lesser penalty. Therefore, a theory of consent based upon the motive of the actor does not seem to be helpful.

(7) Consent is effective only with respect to cases where one may waive a right by a valid contract. If such contract is illicit or against public policy, consent is not effective. For instance, blood transfusions, skin grafts are not against public policy. However, when is a contract against public policy? Are all types of exculpatory clauses against public policy?

(8) Consent is effective depending upon its legal nature. Being a juridical act, it must not be against public policy. We are back to the basic question, when is consent effective?

To conclude, in the absence of an express general provision in the Criminal Code dealing with consent, it is impossible to state with any degree of accuracy when consent is legally effective.

It should be recognized that whereas some of the rights to be enjoyed by human beings can be waived, others cannot. In other words, the protection and enforcement of some rights depend upon the victim's will. A right whose infringement does not immediately and directly injure the State can be waived. Thus, the State may intervene only where the victim has not consented to their infringement. Criteria must be found in order to determine which rights the State protects directly and those it protects indirectly. Such a search involves the scope of the maxim volenti non fit injuria.

In some cases, the penal law protects the rights of individuals objectively, without taking into consideration the victim's consent, on the basis of the public interest so as to protect society in general. The prevention or punishment of offences against the public good does not depend upon the will of the victim. These rights are not subjective rights; they are objectively protected rights because society must be protected. In such a case consent can never be effective.

When the right is subjective, consent is effective only if it is a right that may be waived.

61. See however, Criminal Code, s. 224.

62. E.g., Criminal Code, 8. 14 (right to life). 
Furthermore, the right to be waived should be an individual right (of which an individual may be the subject) and not a collective right (of which society as a whole is the subject). With respect to collective rights, consent cannot remove the illicit character of the act.

In the case of subjective individual rights, some are of a public and some are of a private nature. Consent to the infringement of some public rights (for example, political rights, civil rights) is not effective but may be effective with respect to the right of personal freedom. More generally, is it possible to consent to the infringement of rights guaranteed in the Bill of Rights? 3

Even if the subjective individual right is of a private nature, this does not mean that consent will be effective. The law may impose some limits to the exercise of private rights. It would seem that not all private rights should be able to be waived. The victim's consent should not be effective with respect to rights which he must exercise or in cases where he is forbidden to inflict injury upon himself. If the victim cannot do the act, $a$ fortiori his consent should not be effective to allow another person to do that act (nemo plus juris transferre potest quam habet ipse). What criteria can be used in order to determine whether or not a private subjective right can be waived so that consent will or will not be effective?

Consent should be effective and take away the illicit character of an act vis à vis all private, individual, subjective rights except where the exercise of this right is of a direct and immediate interest to the State independently of the will of the individual involved.

When the State sanctions an attempt against the integrity of human life and allows the subject of the right to life to bring a civil action or lay an information, its aim is to protect him and to allow him to enjoy his life. However, for the State, the life of this citizen represents an asset. The State has a direct and immediate interest in protecting and preserving such life because the consenting person is a potential producer of goods, of children, etc. Here the interest of the State is greater than the interest of the individual. Consent of the subject of the right is effective and renders legal its infringement only when the right does not involve a direct and immediate social usefulness for the State. In such a case, the interest of the State to protect the consenting person is indirect. The State only wants to make sure that such person is able to exercise the right in question. When the right is individually private of itself, independent of the individual, and of immediate and direct social interest to the State, consent should not be effective as the State not only wishes to ensure that the individual can enjoy it but also wishes to preserve its social usefulness. ${ }^{64}$

The difficulty lies with the determination of those private rights in which the State has a direct and immediate social interest and those in which it has not. Which rights are protected and which are not?

(c) Criteria

Fahmy Abdou ${ }^{65}$ is of the opinion that consent to the infringement of an individual subjective private right should be effective and remove the illicit character of the act:

63. R.S.C. 1970, Appendix III, 8. 1(a).

64. Fahmy Abdou, n. 6. Ch. III, 81 et seq.

65. Supra, n. 6 at 139-140. 
(1) in cases where the effect of consent is specifically indicated in the law, or where it is to be derived from the definition of the offence or an analysis of its elements in the relevant law. In some cases, the law itself indicates that absence of consent is an element of the offence so that if the victim consented to the infringement of the right, there is no offence.

(2) where the law is silent on the question of the effect of consent and no direct State or social interest is involved. Also, often the nature of the offence is such that absence of consent is one of its elements, although not specifically mentioned in the text of the law, so that if consent exists, there is no offence.

(3) in the case of a private property right.

(4) in the case of private rights and the right to liberty where a civil action can only be brought by the victim or upon his complaint in the case of a criminal prosecution.

(5) in cases where the infringement of the right constitutes a minor offence.

In order to determine whether or not a right can be waived or infringed, it is necessary to examine the legal provision which protects the right as it may indicate the basic social interest involved.

(ii) Criminal Law

In some types of offence, absence of consent on the victim's part is essential. A finding of consent negates the offence. An example of this type of offence is rape:

143. A male person commits rape when he has sexual intercourse with a female person ...

(a) without her consent, ...

The non-criminal act of sexual intercourse becomes a serious criminal offence by the lack of consent on the part of the victim. Similarly, kidnapping must be against the victim's will. ${ }^{66}$ In the case of child stealing, the consent of the child is no defence, but the consent of the parent or guardian is a bar to conviction provided, of course, that there is no fraud or duress involved. ${ }^{67}$

Common assault and assault causing bodily harm have been the subject of much discussion with regard to whether or not consent to the infliction of injury will be recognized as a defense. In Canada, section 244 of the Criminal Code expressly states that absence of consent is an essential element of the offence:

244. A person commits an assault when (a) without the consent of another person or with consent, where it is obtained by fraud, he applies force intentionally to the person of the other, directly, or indirectly.

The English courts have been concerned with the question of whether or not an alleged assault constitutes conduct criminal in itself which could not be excused by the victim's consent. Canadian courts, being faced with the specific statutory requirement of absence of consent, have approached the problem differently. The finding of consent negates the offence of assault. However, it must be determined whether the acts exceeded the scope of the victim's consent. If they did, they constitute

66. Criminal Code, 8. 247.

67. Perkins, supra, n. 16 at 182. 
assault. Although strictly speaking, the offences of common assault and assault causing bodily harm belong to the category of offences which require an absence of consent, they have undergone a judicial metamorphosis and, for the purposes of this article, belong more properly to offences where consent may or may not be a defence, a category which will be dealt with separately.

As mentioned earlier, there are certain offences to which no one can give legal consent. In effect this means that the law holds certain values to be more important than free choice or individual freedom. An example of this is the sanctity of life. Section 14 of the Criminal Code provides that:

No person is entitled to consent to have death inflicted upon him, and such consent does not affect the criminal responsibility of any person by whom death may be inflicted upon the person by whom consent is given.

Apart from murder, this section covers suicide pacts and euthanasia. Despite the controversy surrounding euthanasia and recent decisions such as that rendered by the Supreme Court of New Jersey in the famous case of Karen Quinlan,67a euthanasia continues to be culpable homicide in Canada by virtue of section 14.

Consent has long been held to be no defence to "unnatural acts", such as buggery or bestiality, often grouped together under the heading of sodomy. In England, section 12 of the Sexual Offences Act of 1956 specifies that both parties, even if consenting, are equally guilty. ${ }^{68}$ However, if one of the parties is a child, he will not be considered responsible. ${ }^{69}$ In Canada, consenting parties over twenty-one years of age are free from liability but the mere fact that one of the parties is under twenty-one will not automatically rule out consent as a defence. ${ }^{70}$ In the case of children, consent is no defence to a charge of having sexual intercourse with a female under the age of fourteen, or indecent assault on a child under fourteen. ${ }^{71}$

Duelling, once a popular activity in the 17 th and 18th centuries, began to be punished in the courts in the 19 th century. ${ }^{72}$ Loss of face became to be regarded as of lesser importance than preserving human lives. Despite the outdated nature of the offence, duelling remains an offence by virtue of section 72 of the Criminal Code. This section, however, covers only the actual agreement or challenge to have a duel. If a duel is held and death or injury results, the perpetrator of the offence would be open to criminal prosecution, and the consent of his opponent would be of no avail to him.

Mayhem or maiming, was at one time an offence under the common law. Russell defines maining as "a bodily hurt whereby a man is rendered less able in fighting, to defend himself or to annoy his adversary". ${ }^{73}$ The injury must not be one which simply disfigures the man, such as cutting off his ear or his nose. Since the policy behind the offence was that the

67a. 355 A. (2d) 647 (1976)

68. Russell, supra, n. 16 at 678 . Also Smith and Hogan, supra, n. 16 at 357.

69. Russell, supra, n. 16 at 678 .

70. R. v. St. Pierre (1964), 17 C.C.C. (2d) 489, 3 O.R. (2d) 642 (Ont. C.A.).

71. See Criminal Code, s3. 140, 148. Without s. 140, by virtue of 8 . 7(3) an accused could argue the child's common law capacity to consent as a defence to the charge against him. In England, the Sexual Offences Act 1967 incorporated a similar provision whereby it is not an offence for two men to commit buggery or gross indecency, provided that both parties consent to it, both are twenty-one years old or older, and the act is committed in private. However, it continues to be an offence for a man to commit buggery with a woman, despite her consent.

72. See discussion in Glanville Williams, Consent and Public Policy [1962] Cr. L. Rev. 74 at 77.78.

73. Russell, supra, n. 16 at 625. 
King would be deprived of able men to serve him in the army, the injury had to render the man less able for fighting. ${ }^{74}$ The consent of the victim was of course no defence. Today, maiming is to be found in section 228 of the Criminal Code:

228. Everyone who, with intent

(a) to wound, maim or disfigure any person, ... causes bodily harm in any way to any person, . . . is guilty of an indictable offence and is liable for imprisonment for 14 years.

As recently as 1962, in the case of $R$. v. Schultz, ${ }^{75}$ the Supreme Court of Alberta defined maiming as injuring a person so that he is less able to fight and defend himself. Consent is not mentioned in the section. If it is proven that the person intended to wound his victim or to maim him, presumably the consent or its absence on the part of the victim is irrelevant. Here the State has a direct interest in protecting the right to physical integrity.

It has long been held that consent is no defence to a charge of assault arising from a prize fight. While the law on this subject has been very clear, the definition of the expression "prize fight" has not always been so. In Smith and Hogan on Criminal Law, it is defined as "a fight without gloves, or otherwise likely to cause more serious injury than boxing under the Queensbury rules". ${ }^{76}$ In section $81(2)$ of the Criminal Code, a prize fight is defined as:

... an encounter or fight with fists or hands between two persons who have met for that purpose by previous arrangement made by or for them, but a boxing contest between amateur sportsmen, ... . or any boxing contest held with the permission or under the authority of an athletic board or commission or similar body established by or under the authority of the legislature of a province for the control of sport within the province, shall be deemed not to be a prize fight.

On the authority of this section, anyone who participates in any way in a prize fight is guilty of an offence punishable by summary conviction.

Probably the most difficult category of offences is that where consent may or may not be a defence, depending upon the circumstances of each case. The offence most frequently discussed under this heading is that of assault, which properly includes the offence of battery. As mentioned previously, courts in England and in Canada have taken slightly different views with respect to the effect of consent.

Among the many cases that deal directly or indirectly with the question of consent as a valid defence to a charge of assault, the two that most readily come to mind are The Queen v. Coney and Others, ${ }^{77}$ and $R$. v. Donovan. ${ }^{78}$ Although Coney was concerned with the question of whether or not a mere spectator at a prize fight was guilty in law of an assault, the case has become famous for the comments it contains as to the nature of an assault. Cave J. said:79

The true view is, I think, that a blow struck in anger, or which is likely or is intended to do corporeal hurt, is an assault, but that a blow struck in sport, and not likely, nor intended to cause bodily harm, is not an assault, and that, an assault being a breach of the peace and unlawful, the consent of the person struck is immaterial.

74. Id. Also Smith and Hogan, supra, n. 16 at 288.

75. (1962), 133 C.C.C. 174,38 C.R. 76 (Alta. S.C. App. Div.).

76. Supra, n. 16 at 287-288. Also see Williams, supra, n. 72 at $78-80$ for a discussion of prize fights.

77. (1882), 8 Q.B.D. 534.

78. [1934] 2 K.B. 498,50 T.L.R. 656.

79. Supra, n. 77 at 539. 
Cave J.'s approach centers on the true intent of the player and makes mens rea a prerequisite to a conviction for assault. More importantly, however, the above passage means that once the court has found that an assault has taken place, consent is no defence. The intent of the player is only relevant insofar as it determines whether or not his actions constituted an assault in law.

In the same case, Stephen J. expressed this view:80

The principle as to consent seems to me to be this: When one person is indicted for inflicting personal injury upon another, the consent of the person who sustains the injury is no defence to the person who inflicts the injury, if the injury is of such a nature, or is inflicted under such circumstances, that its infliction is injurious to the public as well as to the person injured.

Here we have the view that consent can be a defence to assault, depending on the nature of the assault. The question to be asked is, what circumstances will make the infliction of bodily harm injurious to the public as well as to the victim? Stephen J. answers this question by pointing out that "it is against the public interest that the lives and the health of the combatants should be endangered by blows", 81 and goes on to say that public interest is further affected by the fact that prize fights are "disorderly exhibitions, mischievous on many obvious grounds". 82 Presumably then, while the activity during which injury was sustained does not have to be of redeeming social value, neither must it be contra bonos mores or more generally, against public policy. With respect to the actual injury to the person, it is the degree of the injury that is important: 83

In cases where life and limb are exposed to no serious danger in the common course of things, I think that consent is a defence to the charge of assault, even when considerable force is used, as, for instance, in cases of wrestling, single stick, sparring with gloves, football, and the like; but in all cases the question whether consent does or does not take from the application of force to another its illegal character, is a question of degree depending upon circumstances.

Here we have a totally different and, it is submitted, a better test than that set out in Cave J.'s judgment. Instead of trying to decide whether or not the person who struck the blow intended to harm his victim, we have an approach whereby the actual injury sustained and the activity itself are both analyzed in terms of their potential harm to the consenting victim and society in general.

However, it is the approach of Cave J. which seems to have been followed in $R$. v. Donovan, where it was held that if an act is unlawful in itself, no amount of consent will render it lawful.84 "Unlawful" was defined as follows: 85

As a general rule, . . . it is an unlawful act to beat another person with such a degree of violence that the infliction of bodily harm is a probable consequence, and when such an act is proved, consent is immaterial.

The exceptions cited to this rule were such "manly diversions" 86 as contests which encourage the development of physical strength and

\footnotetext{
80. Supra, n. 77 at 549.

81. Id.

82. Id.

83. Id.

84. Supra, n. 78 per Swift J. at 507 (K.B.).

85. Id.

86. Id. at 508 .
} 
skills. Blows inflicted in sport or play, where there was no intention to cause harm, were also considered harmless. However, after saying that no consent will render an unlawful act lawful, Swift J. goes on to say that "there are, however, many acts in themselves harmless and lawful which become unlawful only if they are done without the consent of the person affected".87 As Glanville Williams quite justly points out, this is: ${ }^{88}$

... nothing more than a tautology. The first three sentences say merely that if an act is a crime irrespective of consent, then consent is no defence, while the last says that if the act is a crime only when done without consent, then consent is a defence. In each case the conclusion is wrapped into the premises.

The issue before the court was not satisfactorily decided "merely by an unsupported assertion that the act was unlawful".89 We are therefore forced to return to Coney as an authority. Thus, it appears that intent and degree of force are cumulatively relevant to determine unlawfulness and that intent is only relevant when the degree of force is below a certain level acceptable in the circumstances.

In Canada, perhaps by virtue of section 244 which unequivocally states that consent is a defence to assault, the courts have taken a different approach. This approach pays lip service to the requirements of section 244, while at the same time it neatly sidesteps its possible dangerous effects. In other words, in cases where the degree of bodily harm inflicted on the victim is such that it would seem to be against public policy to permit the conduct to go unpunished, the courts have satisfied both the statutory requirement of section 244 and the public conscience by asserting the following: consent is an absolute defence to a charge of assault, but where it is found that the accused's conduct went beyond the scope of the victim's consent, that behaviour which was not covered by the consent must be punished. In $R$. v. MacTavish, ${ }^{90}$ two schoolboys agreed to a "fair fight". There was no question that the victim's consent was anything less than informed and voluntary. However, at the beginning of the fight, the victim fell and the appellant proceeded to kick him in the face, thereby causing him serious bodily harm. The New Brunswick Supreme Court, Appeal Division, held that the victim had indeed consented to a fair fight; however, kicking has never been considered as behaviour proper to a "fair fight". Therefore, the appellant's behaviour exceeded that anticipated by the victim and was not covered by his consent. 11 The basic issue seems to be whether or not the conduct of the recipient of the consent exceeded the limits of such consent. If this is the case he acted without the victim's consent.

In Regina v. Dix, ${ }^{92}$ the Ontario Court of Appeal was faced with a similar fact situation. Here, the two parties were engaged in a "scuffle" and, by mutual agreement, they left the premises and had a fight outside. During the fight, the victim was "severely injured", although his injuries are not specified. Gale C.J.O. said: "We can find no evidence, and have been referred to none, which would warrant a finding that the actions of the appellant were outside the scope of the consent which had been given." However, he was careful to point out that "the two parties

87. Id. at 507.

88. Supra, n. 72 at 156.

89. Id.

90. (1972), 8 C.C.C. (2d) 306, 20 C.R.N.S. 235, 4 N.B.R. (2d) 876.

91. Supra, n. 90 , per Hughes C.J.N.B. at 208 (C.C.C.).

92. (1972), 10 C.C.C. (2d) 324 (Ont. C.A.).

93. Id. at 325 . 
consented to a fight and the fight was had in a normal manner, if I might use that phrase. That is not the same situation as in $R$. v. MacTavish .... where the combatants expressly, or impliedly, agreed to a fair fight and the accused did not fight fairly,"94

A similar approach was taken in Abraham v. The Queen, ${ }^{95}$ where consent was raised as a defence to a charge of common assault when the accused kicked his wife in the ribs and pulled her by the hair. The Quebec Court of Appeal held that the defence of consent is a matter of fact for the judge to determine, and once it is determined that consent was in fact obtained, it must be seen whether the accused's actions were covered by that consent.

In the matter of injuries sustained by players in the course of a sporting event, the current opinion seems to be that all players accept a certian degree of risk and potential injury when they agree to participate in a game such as hockey. ${ }^{96}$ However, the issue is one of drawing the line, so to speak. "[N]o athlete should be presumed to accept vicious, unprovoked or overly violent attack."97 The approach seems to be similar to that of Stephen J. in $R$. v. Coney, where the degree of injury to the combatants was considered decisive in deciding whether or not consent was a defence. If the injury sustained is one which could reasonably be expected to have happened in the regular course of a game, the players will not be guilty of assault. However, if the injury is not within the scope of the normal risks that are assumed to be taken by the players, it will be held to be an assault or an assault causing bodily harm.98

Surgical operations can, of course, also constitute the crime and the tort of assault and battery, if performed without the consent of the patient. However, this is only a general rule and the exceptions are several. In Canada, section 45 of the Criminal Code protects most physicians or surgeons from criminal liability although the section is not limited to them:

45. Everyone is protected from criminal responsibility for performing a surgical operation upon any person for the benefit of that person if

(a) the operation is performed with reasonable care and skill, and

(b) it is reasonable to perform the operation, having regard to the state of health of the person at the time of the operation is performed and to all the circumstances of the case.

The effect of this section is potentially sweeping, since most operations are for the benefit of the person being operated upon and it is safe to assume that such operations are performed with reasonable care and skill. Furthermore, section 45 is not confined to situations where an unconscious or disabled person is the subject of the surgical operation and is unable to give a consent. It applies to both consensual and non consensual surgery. However, the section may take away the patient's right to refuse surgical operation although, usually it is available as an answer to a charge arising out of a surgical operation performed on an unconscious patient. Thus, theoretically, a Christian Scientist would not

94. Id. at 326.

95. (1974), 26 C.R.N.S. 390 (Que. C.A.).

96. See R. v. Maki (1970), 1 C.C.C. (2d) 333; R. v. Green (1970), 2 C.C.C. (2d) 442; R. v. Watson (1975), 26 C.C.C. (2d) 150. See also comment by Brent (1976) 32 Cr. R. (N.S.) 121; Hechter, The Criminal Law and Violence in Sports (1977), 19 Crim. L.Q. 425.

97. Maki, id. per Carter, Prov. Ct. J., at 336.

98. Id. Also Watson, supra, n. 96 at $156-8$.

99. Medical procedures are discussed in greater detail later on in this article. 
be able to charge the operating surgeon with criminal assault after having his appendix removed without his consent and against his religious principles. Of course, the surgeon may be civilly liable for battery. In practice, section $\mathbf{4 5}$ is invoked together with the common law defence of necessity. ${ }^{100}$

Since the section stipulates that the operation must be for the benefit of the person, it excludes operations such as those necessary to remove an organ from a donor of a kidney transplant. It also excludes a whole host of other operations, such as rhinoplasties (commonly called nose jobs), breast reduction or augmentation, sex change operations, and, presumably, sterilization unless the latter is performed for health reasons. The consent of the patient becomes necessary to free the surgeon from criminal responsibility. However, it must first be determined whether the operation, which by necessity inflicts a certain amount of bodily harm upon the patient, is an activity which can be legally consented to. If the approach of Stephen J. in Coney is followed, it seems obvious that most of these operations can be legally consented to. While cosmetic surgery may not have a significant social value attached to it, it is difficult to see how it could be injurious to the public. As for organ donation, the motive of the donors is highly laudable.

Sterilization raises some difficult problems. The most famous comments on the subject were made by Lord Denning in the case of Bravery v. Bravery. ${ }^{101}$ Lord Denning's seemingly unsolicited remarks were clearly obiter and the rest of the court took care to disjoin themselves from them. Lord Denning referred to Stephen J.'s judgment in Regina v. Coney and took the view that consent was no defence to sterilization since the operation, unless undergone for health reasons, was clearly injurious to the public: 102

When it [sterilization] is done with the man's consent for a just cause, it is quite lawful; as, for instance, when it is done to prevent the transmission of an hereditary disease. But when it is done without just cause or excuse, it is unlawful, even though the man consents to it. Take a case where the sterilization operation is done so as to enable a man to have the pleasure of sexual intercourse, without shouldering the responsibilities attaching to it. The operation then is plainly injurious to the public interest. It is degrading to the man himself. It is injurious to his wife and to any woman whom he may marry, to say nothing of the way it opens to licentiousness; and, unlike contraceptives, it allows no room for a change of mind on either side. It is illegal, even though the man consents to it.

This is the only judical pronouncement on the issue of sterilization. However, this view seems not to have been followed over the years, as can be witnessed by the large number of vasectomies and tubal ligations which take place everyday, and which do not result in criminal prosecutions.

Abortion, or procuring a miscarriage under section $251(1)$ of the

100. See Morgentaler v. The Queen (1975), 20 C.C.C. (2d) 449, 53 D.L.R. (3d) 161 (S.C.C.). The defence of necessity has been preserved as a common law defence under 8. 7(3) of the Criminal Code. It has never been raised successfully in a criminal case in Canada. "If it does exist it can go no further than to justify non-compliance in urgent situations of clear and imminent peril when compliance with the law is demonstrably impossible. No system of positive law can recognize any principle which would entitle a person to violate the law because on his view the law conflicted with some higher social value." Per Dickson J. at 497 (C.C.C.). See in general Skegg, A Justification for Medical Procedures Performed Without Consent (1974), 90 L.Q. Rev. 512 Note that necessity was held proper as a successful defence in the second Morgentaler appeal to the Quebec Court of Appeal, and succeeded in his third trial, the re-trial of the first. See Leigh, Necessity and the Case of Dr. Morgentaler, [1978] Cr. L. Rev. 151; Dickens, The Morgentaler Case: Criminal Process and Abortion Law (1976), 14 Osgoode Hall L.J. 229 at 266 et seq. What if a patient with a communicable disease refuses treatment and leaves hospital? Could such a patient be incarcerated and forced to accept therapy without consent on the ground that he is a risk to the public and to himself? 
Criminal Code, is not covered by section 45 , as was held in Morgentaler v. The Queen. ${ }^{103}$

One may well ask with Glanville Williams, "what public interest is to be served by using the criminal law to prevent adults inflicting discomfort on each other, or submitting to any form of surgical operation, if they so wish?"104 Professor Williams himself believes the answer is "none", with the stipulation that if there is a danger of injury to the public, the law has a right to step in and impose its limitations on the parties involved.105 Thus, we encourage individual freedom with the condition that it does not infringe the rights and freedom of others.

Strauss ${ }^{106}$ suggests that the best standard to be applied is that of analyzing the behaviour in question and deciding whether or not it is contra bonos mores. The factors to be considered would be the motives of the perpetrator as well as those of the injured party. Society itself must be taken into consideration: 107

In a society where the freedom of the individual is esteemed highly, he will be accorded a greater measure of autonomy in waiving his interests. The nature and seriousness of the injury and the nature of the object attacked must play an important role. The more valuable the object attacked-e.g. life, liberty, bodily integrity-the more likely it is that the aggression will be deemed in conflict with good morals.

By making sure that only activities which are not injurious to the public interest will be allowed, and by ascertaining that only those capable of understanding are permitted to consent, the criminal law fulfils its original function of protecting the interests of society in general.

\section{(iii) Private Law}

Fleming states: 108

Voluntary assumption of risk as a defence to negligence corresponds to the plea of consent in actions for intended harm. Both are expressions of the same philosophy of individualism, that no wrong is done to one who consents: volenti non fit injuria. The basic idea is that the plaintiff, by agreeing to assume the risk himself, absolves the defendant from all responsibility for it. The latter's duty of care is thus suspended. ${ }^{109}$

The maxim volenti non fit injuria has been applied by the courts in the common law provinces when no public interest was involved. Consent negates the wrongful element of the defendant's act in intentionally or unintentionally invading the plaintiff's interest. It amounts to an implied waiver of responsibility. This means, for instance, that at common law, a physician would not be liable in an action for the tort of assault and battery or trespass to the person when he did something to a patient for which he had obtained an informed consent. Such consent where it exists also bars an action based on the tort of negligence.

For instance, in Kelly v. Hazlett, Morden J. stated: ${ }^{110}$

Broadly speaking, a battery is the intentional, unconsented to, touching of the person of the plaintiff by the defendant, while negligence (in the context of a case such as this)

101. [1954] 1 W.L.R. 1169, [1954] 3 All E.R. 59 (C.A.).

102. Supra, n. 101 at 1180 .

103. Supra, n. 100.

104. Williams, supra, n. 72 at 159.

105. Id.

106. Bodily Injury and the Defence of Consent (1964), 81 South African L.J. 179 at 183.

107. Id. at 183-184.

108. Law of Torts (4th ed, 1974), 239. See also p. 77.

109. Assumption of risk must be distinguished from contributory negligence although it has been suggested that consent may amount to contributory negligence.

110. Supra, n. 23 at 310 (O.R.), 555-6 (D.L.R.). 
consists of the substandard execution of a duty of care by the doctor resulting in damage. The doctor's general duty of care includes not only the duty to exercise due skill and competence in diagnosis and treatment but also to give reasonable information and advice to the patient. This latter duty is one of variable content depending on the circumstances of the case and the determination of its proper scope is very often a matter of considerable difficulty.

The issue of "informed" consent can arise in both battery and negligence cases: with respect to the former a lack of proper information communicated by the doctor to the patient can vitiate an apparent consent while, with respect to the latter, failure to see to it that the patient is properly advised can amount, in certain circumstances, to an act of negligence. ... .

How the case is pleaded in many cases is more than a matter of mere academic interest. It will have important bearing on such matters as the incidence of the onus of proof, causation, the importance of expert medical evidence, the significance of medical judgment, proof of damage and most important, of course, the substantive basis upon which liability may be found. ...

To make out a case of battery, the plaintiff need only prove that what was done differed substantially from that to which he assented. As Haines J. pointed out in Reibl v. Hughes:111

There is no issue for which medical evidence is required. Nor is there a question of causation: the plaintiff need not show that had the proper information been communicated consent would have been withheld. The onus to prove consent as a defence falls upon the defendant doctor. Recast in terms of the obligation on the defendant, the law of battery in effect places on a physician a strict duty to explain to his patient, in language which the patient can understand, the essential nature and quality of the treatment he is to undergo.

His Lordship also said that while the principle can be stated with relative simplicity, it is difficult to apply it to particular cases. To overcome this difficulty: ${ }^{112}$

$\ldots$ it is reasonable to look at the matter of informed consent, as far as an alleged battery is concerned, from the point of view of what information was communicated. If the basic nature and character of the operation performed is substantially that of which the plaintiff was advised, and then agreed to, then there has not been an unconsented to invasion of the person of the plaintiff, regardless of any failure to disclose any collateral risks flowing from the operation. However, such failure, if it can be shown to have resulted in damage to the patient, and was not justified by reasonable medical considerations, may properly be subject-matter for a claim based on negligence. This approach ... seems to me to strike a reasonable balance in the complex of interests, rights and duties subsisting in the patient-doctor relationship, as well as being consistent with basic concepts of the law of torts.

Strictly speaking, the battery approach should be confined to cases where the physician intentionally deviated from practice not intended to be beneficial to the patient. Yet, an inadequate explanation of the effects and risks of an operation could result in an apparent consent being ineffective and hence not a defence to a claim for assault and battery.

\section{With respect to a claim of negligence: ${ }^{13}$}

... the issue of informed consent to treatment is a concomitant of the physician's duty of care. A surgeon's duty to exercise due skill and care in giving his patient reasonable information and advice with respect to the risks specifically attendant on a proposed operative procedure arises out of the special relationship between them. It is a particular case of the duty which is cast on professional persons in a fiduciary position called upon specifically or by implication to give information or advice to a client intending and entitled to rely on his statements to determine his course: Nocton v. Lord Ashburton,

111. Supra, n. 27 at 311 (O.R.).

112. Per Morden J. in Kelly v. Hazlett, supra, n. 27 at 558 (D.L.R.). In Canada the great majority of cases involving the issue of consent and informed consent have been pleaded and decided as battery cases, but there have been exceptions. See Rozovsky, n. 26 at 104 et seq.

113. Reibl v. Hughes, supra, n. 27, per Haines J. at $42-43$ (D.L.R.); McLean v. Weir et al., supra, n. 27. 
[1914] A.C. 932; Kenny v. Lockwood, [1932] O.R. 141. That duty does not require warning the patient of the dangers incident to or possible in any surgical procedure, such as the dangers of anaesthesia or the risk of infection, matters which men of ordinary knowledge are presumed to appreciate. It relates to the specific risks within the surgeon's knowledge peculiar to the contemplated treatment. The scope of this professional duty of care is defined by the evaluation of a variety of interrelated factors which bear uniquely on each case, factors such as the presence of an emergency requiring immediate treatment; the patient's emotional and intellectual make-up, and his ability to appreciate and cope with the relevant facts; the gravity of the known risks both in terms of their likelihood and the severity of this realization. The difficulty evident for the independent evaluation of these factors by a lay tribunal has caused the law of this jurisdiction to leave the definition of the scope of this duty in any particular case a matter essentially of medical judgment, one to be determined by the court on the basis of expert medical evidence.

In Quebec, the relationship between physician and patient is contractual. ${ }^{114}$ Failure to disclose and to obtain consent may amount to a breach of the physician's contractual obligation. However, it has been argued that when no consent is given or when consent has been exceeded, the physician's liability is delictual.115 In both the civil law and the common law, it may be against public policy for one person to exempt the other from responsibility for an intentional fault or for what would otherwise be a breach of a duty owed to him.

\section{(a) Private Law-Criminal Law Dichotomy}

Since consent is part of the general theory of law, its effects should be the same in all branches of the law. If consent is effective to make licit a civil wrong, it should be equally effective in the criminal field, and vice versa. An act forbidden by the criminal and the private law which becomes lawful with respect to its civil effects as a result of consent, should also become licit with respect to its criminal law effects. There is need for a unified doctrine not only as to the effects of consent but also with respect to the nature and elements of consent.

\section{(iv) Effect of a Consent that is Null and Void}

A consent that is null and void does not eliminate the objective element of an offence. It may, however, have an effect on the subjective element of the offence, on the right to prosecute or to bring a civil action for damages, or on the penalty to be imposed. This may be the situation when, as a result of an error as to facts, the offender believes that consent exists, or that it is valid, or that the consenting party has the power to consent. For instance, in the case of the crime of rape, which consists in having sexual intercourse with a woman with intent to do so without her consent or with indifference as to whether or not she consented, it cannot be committed if that essential mens rea is absent. Thus, if an elleged offender in fact believed that the woman had consented, whether or not the belief was based on reasonable grounds he could not be found guilty of rape.116 The offender may also believe that consent was given to him, or that it pertains to a certain act while it pertains to another act. Lastly, he may not know that consent has been revoked.

Errors as to the law are also possible. In such a case the error may relate to the question whether the right belonging to the victim may be waived. The offender may believe that consent is valid because he ignores

114. X. v. Mellen, [1957] B.R. 389.

115. Beausoleil v. La Communauté des Soeurs de la Charité de la Providence, [1965] B.R. 37. See Baudouin, La responsabilité civile délictuelle (1973), no. 224, and Crépeau, La responsabilité civile du medecin et de l'établissement hospitalier (1956).

116. See Director of Public Prosecution v. Morgan, [1975] 2 All E.R. 347 (H.L.). 
that a juridical act without a lawful cause or consideration or object is null and void. Finally, he may think that a minor is capable of consenting.

\section{APPLICATION OF GENERAL PRINCIPLES TO THE MEDICAL FIELD}

\section{(A) The Right to Life \\ (i) General}

The right to life is an individual right protected by the penal and the private law. ${ }^{117}$ The victim's consent is no defence ${ }^{118}$ as the State has an immediate and direct interest in the protection of this right even though suicide is not prohibited or punishable.

It may seem inconsistent for the State to allow self-destruction and to forbid such destruction of life by another. The reason why suicide is not punished is that the act is committed by a person who is both the offender and the victim. On the other hand, counselling or aiding a person to commit suicide is punishable irrespective of the social or anti-social motives of the accused. This ties in with section 14 of the Criminal Code.

If the State punishes the person who counsels or aids a person to commit suicide either by considering the act as an offence sui generis which is the case in Canada, ${ }^{119}$ or an omission to help a person in danger, it must $a$ fortiori punish a person who kills a consenting victim. ${ }^{120}$

The State has a direct interest in the lives of its citizens. In the world today, no legislation permits the killing of persons upon their consent although the law of some countries provides for a lesser penalty if certain conditions are met. Where no special provision exists dealing with the effect of consent, the act may be culpable homicide, or it may not be incriminated depending upon the motives of the offender. As noted above, in Canada, consent as such cannot justify the taking of life. The right to life is not a right that can be waived or infringed.

\section{(ii) Suicide}

As an introduction to the subject of homicide on request or with the consent of the victim, it is advisable to further consider suicide as it raises the basic question whether a person has the right to die. The difficulty involved in answering this question is that suicide is a licit act whereas by virtue of section 14 of the Criminal Code the victim cannot render licit a culpable homicide committed by another person.

The laws of the world are not uniform on this question. Most of them do not punish suicide, although some of them punish an attempted suicide or counselling or aiding suicide.

In the case of suicide a person cannot make an agreement with himself. He cannot be the offender and the victim, a subject and an object of the law. He cannot have a right to life and be under an obligation to enforce this right. In other words, an individual does not have legal obligations towards himself. If suicide is not an offence, then those who help a person to commit suicide should not be considered his accomplices since this would suppose a principal offence which does not exist. Thus, a

117. Criminal Code, ss. 196-243. Note that the expression "right to life" is not used in any political sense.

118. Criminal Code, s. 14.

119. Criminal Code, s. 224.

120. Criminal Code, s. 14 
physician who gives his patient the means of killing himself should not be criminally responsible. However, the Criminal Code avoids the difficulty by making the accomplice guilty of an offence sui generis. ${ }^{121}$

If the criminal law does not punish suicide because the victim is both a passive and an active subject of the act, the situation is not the same with respect to the person assisting another to commit suicide. In this case the victim is the person who committed suicide and the offender of this sui generis offence becomes the principal actor. Thus, it is logical to have a special offence in the Code, although the motives for counselling and aiding to commit suicide should be taken into consideration. Proper motives would justify a physician in certian circumstances, although this approach may violate the spirit of section 14 of the Criminal Code. Another view is that motives should not be a complete excuse so as to render the act licit. They would only diminish the penalty.

Consent should not be a justification in the case of the right to life which is a right that cannot be waived or infringed. However, the social or anti-social motives of the agent could be considered as an extenuating or aggravating circumstance.

\section{(iii) Homicide on Request or with the Consent of the Victim}

In the case of homicide on request or with the consent of the victim, the offender's participation is not limited to advice or active or passive assistance and co-operation. The offender is the one who kills the victim as in the case of mercy killing by a physician.

Homicide on request or with the consent of the victim is not recognized in Canada. The act is culpable homicide. Consent does not make the act licit or justifiable. ${ }^{122}$

It could be argued that the killing of a person at his request or with his consent should be excusable or licit if the motives of the person doing the killing are not anti-social. Why should there be a difference between homicide on request or with consent and suicide? It is the wishes or intention of the victim that count, not the material act of giving death. Furthermore, in such cases there is no intention to cause harm, no criminal intent, although the intention to kill exists. It is suggested that there should be a special provision in the Code listing the cases in which homicide should not be severely punished. Section 14 of the Criminal Code is too wide in its present form.

Most writers reject the maxim volenti non fit injuria in the case of homicide on request or with consent because of the general interest of society and of the State. Of course all the elements of homicide are present: a material act likely to cause death, a person alive, the intent to kill, etc. However, motive is not part of the offence, especially since section 14 rejects consent.

It would seem advisable to make homicide upon request or with consent a special offence. The method for obtaining consent as well as motives would be taken into consideration as consent is closely connected with motives. Also, should it make any difference whether homicide is committed at the request of the victim or with his consent? Who took the initiative may be a relevant consideration. Homicide with consent may have to be more severely punished than homicide on request. Perhaps this should be left to the judge's or jury's appreciation. 
In certain cases it may be difficult to distinguish between homicide on request or with consent and aiding suicide. However, the person who aids is not committing a homicide, but a special offence sui generis.

\section{(iv) Euthanasia and the Right to Die}

This analysis leads us to a consideration of euthanasia and the right to die, which involves the distinction between terminating life and abbreviating the process of dying.

\section{(a) Euthanasia}

Euthanasia is the deliberate act of commission or omission to end the life of a person suffering from a painful and terminal illness. It is voluntary or involuntary depending upon whether or not the patient consented to, or requested the ending of his life. It is well established in Canadian criminal law that a positive act of euthanasia constitutes culpable homicide (murder) and that a person is not legally permitted to consent to the infliction of death upon himself by another. ${ }^{123}$ Thus, death given with the consent of the patient or at his request by a positive act is still culpable homicide (murder). ${ }^{124}$ While judges and juries appear to show extreme solicitude towards persons accused of positive euthanasia, the act is clearly illegal in Canada. Actually, euthanasia is a euphemism for culpable homicide.

\section{(b) Right to Die}

Euthanasia by omission has been the object of much discussion as it involves the patient's right to die. Should a physician be allowed to withdraw any supportive therapy and let a terminally ill patient die of his natural death by abstention or omission of care and treatment?

In practice, euthanasia by omission is often administered at the request, or with the consent of, the terminally ill patient. The issue is whether the physician-patient relationship imposes upon the physician the duty to take every step to preserve the patient's life.

It is submitted that a terminally ill patient should have the right to refuse life-prolonging treatment by withholding his consent to the medical postponement of his death. On the other hand, the law should not hold the physician accountable for malpractice when he respects and complies with the patient's decision: ${ }^{125}$

... Provided that the doctor is satisfied that the patient when forbidding further treatment was aware of what he was saying, the short answer must be that he is not in breach of his duty. There is no doubt that his duty extends to informing his patient, if asked, of the nature of his illness and its likely prognosis. In such a way he puts his patient in a position to make a decision which is informed. Once the decision is made he is obliged to respect it. Thus, the doctor on this reasoning incurs no liability under the civil law, nor can he be accused of any crime. To consider the issue in greater detail, the only circumstance under which his omission to treat his patient further could render him guilty of manslaughter is where he has failed to act in a situation where the criminal law imposes on him a duty to act.

There are many objections to voluntary euthanasia: The criteria of incurability are often uncertain; to abstain from treating a patient could be considered against the Code of Ethics of the medical profession or the 
Hippocratic oath; ${ }^{126}$ euthanasia by omission may also violate the provisions of the Criminal Code. ${ }^{127}$

In the absence of consent to prolong treatment, a state of necessity may justify the physician's act done against the will of the terminally ill patient. ${ }^{128}$ On the other hand, the act of the physician in withdrawing treatment may contravene his obligation to assist a person in danger, ${ }^{129}$ or constitute homicide by omission provided there is a legal duty to act. ${ }^{130}$ The physician may also be liable civilly for malpractice or for misfeasance on the ground that once a physician undertakes to render necessary medical services, he remains under a legal duty to perform them if by omitting to do so the life of the patient would be endangered.

To conclude, today, the legal status of the physician who merely withholds treatment at the request of a terminally ill patient is in great dispute. However, in Canada, no physician has ever been indicted or convicted for such an act. In the case of voluntary euthanasia, whether by positive act or by omission, the major difficulty is to insure the voluntariness of the consent by a patient who by definition is a victim of a terminal illness and is either experiencing considerable pain or is drugged. Should voluntary euthanasia be legalized, the way to insure that a person's consent is legally "voluntary" is to require that it be given while he is rational and sane and well before he is in pain or drugged. This could take the form of a declaration in a special document as in the case of a gift of tissue. Before the administration of euthanasia, the attending physician would make sure that the prior declaration of consent is still in accord with the ascertained desire of the patient at that time. Revocation of the declaration would be allowed at any time by a clear act by the patient, or on his order.

\section{(c) Minors and Mentally Diminished Patients}

Where children and mentally ill persons, or patients who are drugged or crazed by pain are involved, persons legally responsible for them or close relatives should not be allowed to give a valid consent on their behalf. ${ }^{131}$

In the case of a minor this would not be legally possible, as his parents or guardian can only consent to treatment not withdrawal of treatment, since the contemplated act must be in the interest of the child. However, since in some jurisdictions, the law only creates a duty to provide medical care recommended by a legally qualified medical practitioner, it could be argued that if, because of an unfavourable prognosis treatment is no longer indicated, parents commit no offence in withdrawing consent to its use.

Where an adult unable to make a decision is involved, relatives should have no authority to consent because of the possible harmful results of such authorization. A conflict of interests is always possible as well as a

126. In Canada, the Code of Ethics of the Canadian Medical Association would seem to allow euthanasia by omission as it provides that an ethical physician will allow death to occur with dignity and comfort when death of the body appears to be inevitable, and may support the body when clinical death of the mind has occurred, but need not prolong life by unusual or heroic means.

127. Ss. 202 (criminal negligence), 205 (homicide), 207 (death which might have been prevented), 209 (acceleration of death), 212 (murder), 198 (duty of persons undertaking acts dangerous to life), 199 (duty of persons undertaking acts).

128. Also Criminal Code, s. 45, although this section only deals with surgical operations.

129. This is the case in some countries.

130. See Criminal Code, 88. 198-199.

131. See Symposium-Mental Incompetents and the Right to Die (1977), 11 Suffolk U.L. Rev. 919-973. 
feeling of guilt on the part of the relatives. There is no doubt that in the case of voluntary euthanasia consent cannot always be satisfactorily obtained.

\section{(d) Conclusions}

Euthanasia should be made a special offence distinct from culpable homicide or be legalized. In the latter case, legalization should be restricted to voluntary euthanasia. If made a special offence, the judge and jury should be able to take motives into consideration. The penalty should be lighter than in the case of culpable homicide. In other words, the physician's motives and the patient's consent would be admissible and mitigate punishment by affecting the sentence to be received upon conviction. Section 14 of the Criminal Code is much too sweeping in the complex world in which we live.

Other countries have dealt with homicide on request or with the consent of the victim. For instance, in Switzerland, homicide on request is a special offence which is not as serious as culpable homicide. Section 114 of the Swiss Penal Code of 1937 provides that: "he who kills a person upon his serious and urgent request, is punishable by imprisonment". ${ }^{132}$ In Italy, the Penal Code of 1930 also considers homicide on request or with the consent of the victim as a special offence. It does not matter who initiated the request or sought the consent. ${ }^{133}$ In Colombia, euthanasia is also a special offence with the difference that consent or request is not necessary, provided the act was committed out of compassion. Mitigated charges and punishment, even judicial pardon are justified on the grounds that the reprehensible nature of the act is reduced by virtue of the motivating compassion of the actor and the consenting plea of the patient. 134

In California the Natural Death $\mathrm{Act}^{135}$ recognizes that an adult person has the right to make a written directive instructing his physician to withhold or withdraw life-sustaining procedures in the event of a terminal condition. $\$ 7188$ provides as follows:

Any adult person may execute a directive directing the withholding or withdrawal of life-sustaining procedures in a terminal condition. The directive shall be signed by the declarant in the presence of two witnesses not related to the declarant by blood or marriage and who would not be entitled to any portion of the estate of the declarant upon his decease under any will of the declarant or codicil thereto then existing or, at the time of the directive, by operation of law then existing. In addition, a witness to a directive shall not be the attending physician, an employee of the attending physician or a health facility in which the declarant is a patient, or any person who has a claim against any portion of the estate of the declarant upon his decease at the time of the execution of the directive. . . .

The directive to physicians must follow a special form:

Directive made this day of (month, year).

I being of sound mind, willfully, and voluntarily make known my desire that my life shall not be artificially prolonged under the circumstances set forth below, do hereby declare:

1. If at any time I should have an incurable injury, disease, or illness certified to be a terminal condition by two physicians, and where the application of lifesustaining procedures would serve only to artificially prolong the moment of my death and where my physician determines that my death is imminent whether or

132. See Pestalozzi-Henggeler, Euthanasia Under the Swiss Code (1961), 15 Southwest L.J. 393.

133. S. 579.

134. Code of 1936, 8. 364. See also Norwegian Criminal Code of 1902, s. 235.

135. Cal. Stats. 1976, c. 1439. 
not life-sustaining procedures are utilized, I direct that such procedures be withheld or withdrawn, and that I be permitted to die naturally.

2. In the absence of my ability to give directions regarding the use of such lifesustaining procedures, it is my intention that this directive shall be honored by my family and physician(s) as the final expression of my legal right to refuse medical or surgical treatment and accept the consequences from such refusal.

3. If I have been diagnosed as pregnant and that diagnosis is known to my physician, this directive shall have no force or effect during the course of my pregnancy.

4. I have been diagnosed and notified at least 14 days ago as having a terminal condition by M.D., whose address is

I understand that if I have not filled in the physician's name and address, it shall be presumed that I did not have a terminal condition when I made out this directive.

5. This directive shall have no force or effect five years from the date filled in above.

6. I understand the full import of this directive and I am emotionally and mentally competent to make this directive.

Signed

City, County and State of Residence

The declarant has been personally known to me and I believe him or her to be of sound mind.

Witness

Witness

In the case of patients confined in skilled nursing facilities who are insulated from a voluntary decision making role by virtue of the custodial nature of their care, the Act requires special assurance that they are capable of wilfully and voluntarily executing a directive. The directive may be revoked at any time by the declarant, without regard to his mental state of competency, by a variety of methods including a verbal declaration. No criminal or civil liability exists on the part of any person for failure to act upon a revocation made pursuant to the Act unless that person had actual knowledge of the revocation. If the declarant becomes comatose or is rendered incapable of communicating with the attending physician, the directive remains in effect for the duration of the comatose condition or until such time as the declarant's condition renders him able to communicate with the attending physician. This is a dangerous provision as a comatose declarant who has changed his mind with respect to a directive he had signed some years previously will not be able to indicate his present intention to revoke the directive. Also a directive supposed long lost by the patient may suddenly turn up in the physician's file. Should the physician be under an obligation to ask whether such directive is still in force?

Sections $7190-7191$ provide that:

\$7190. Civil liability or guilt of criminal act or unprofessional conduct.

No physician or health facility which, acting in accordance with the requirements of this chapter, causes the withholding or withdrawal of life-sustaining procedures from a qualified patient, shall be subject to civil liability therefrom. No licensed health professional, acting under the direction of a physician, who participates in the withholding or withdrawal of life-sustaining procedures in accordance with the provisions of this chapter shall be subject to any civil liability. No physician, or licensed health professional acting under the direction of a physician, who participates in the withholding or withdrawal of life-sustaining procedures in accordance with the provisions of this chapter shall be guilty of any criminal act or of unprofessional conduct.

\$7191. Effectuation of directive by attending physician.

(a) Prior to effecting a withholding or withdrawal of life-sustaining procedures from a qualified patient pursuant to the directive, the attending physician shall 
determine that the directive complies with section 7188 , and, if the patient is mentally competent, that the directive and all steps proposed by the attending physician to be undertaken are in accord with the desires of the qualified patient.

(b) If the declarant was a qualified patient at least 14 days prior to executing or reexecuting the directive, the directive shall be conclusively presumed, unless revoked, to be the directions of the patient regarding the withholding or withdrawal of lifesustaining procedures. No physician, and no licensed health professional acting under the direction of a physician, shall be criminally or civilly liable for failing to effectuate the directive of the qualified patient pursuant to this subdivision. A failure by a physician to effectuate the directive of a qualified patient pursuant to this division shall constitute unprofessional conduct if the physician refuses to make the necessary arrangements, or fails to take the necessary steps, to effect the transfer of the qualified patient to another physician who will effectuate the directive of the qualified patient.

(c) If the declarant becomes a qualified patient subsequent to executing the directive and has not subsequently re-executed the directive, the attending physician may give weight to the directive as evidence of the patient's directions regarding the withholding or withdrawal of life-sustaining procedures and may consider other factors, such as information from the affected family or the nature of the patient's illness, injury, or disease, in determining whether the totality of circumstances known to the attending physician justify effectuating the directive. No physician, and no licensed health professional acting under the direction of a physician, shall be criminally or civilly liable for failing to effectuate the directive of the qualified patient pursuant to this subdivision.

The withholding or withdrawal of life-sustaining procedures from a patient in accordance with the provisions of the Act does not constitute a suicide or have any effect on life insurance.

The Act does not impair or supersede any legal right or legal responsibility which any person may have to effect the withholding or withdrawal of life-sustaining procedures in any lawful manner, nor does it condone or authorize or approve mercy killing, or permit any affirmative or deliberate act or omission to end life other than to permit the natural process of dying. ${ }^{136}$

It seems that under the Act, a physician will often have to seek legal opinion (for example, whether the directive is valid) before withholding or withdrawing life-sustaining procedures.

A patient should always be able to consent to ordinary life-sustaining procedures during a terminal condition in spite of a directive.

To conclude this discussion, it is worth quoting the medical directives adopted by the Swiss Academy of Medical Sciences in November 1976 together with the accompanying commentary as they provide guidelines that could be adopted in Canada.

\section{LE TRAITEMENT MEDICAL}

(a) Quand le patient a été convenablement renseigné et qu'il est capable de discernement, sa volonté quant au traitement doit etrê respectée, même si elle ne correspond pas aux indications de la médecine.

(b) Quand le patient est incapable de discernement, que ce soit parce qu'il est inconscient ou pour une autre cause, les normes de la médecine aideront le médecin à fixer sa ligne de conduite qui, par ailleurs, se situe dans le cadre de la gestion sans mandat. Le médecin doit alors tenir compte de ce que l'on peut présumer de la volonté du patient. Les proches de celui-ci doivent être entendus, mais juridiquement la décision dernière appartient au médecin. Si le patient est mineur ou interdit, les mesures médicales ne doivent pas être réduites ou suspendues à l'encontre de la volonté des parents ou du tuteur.

136. In Ontario see Bill 3 (private member's Bill), 4th Session, 30th Legis.1977, entitled, "An Act Respecting the Withhoiding or Withdrawal of Treatment where Death is Inevitable", which was patterned after the California legislation. The Bill, which died on the order paper, was not reintroduced after the election. 
(c) S'il existe des possibilités d'amélioration chez un malade ou chez un blessé en danger de mort, le médecin prend les mesures propres à le guerir et à le soulager.

(d) Chez les mourants et chez les malades et les blessés en danger de mort-dont l'affection évolue de façon irreversible vers une issue fatale, et-qui ne pourraient ultérieurement avoir une vie relationnelle consciente, le médecin se contente de calmer les souffrances, mais il n'est pas obligé d'utiliser toutes les ressources therapeutiques qui pourraient prolonger la vie.

(1) Le médecin est lié par la volonté d'un patient capable de discernement, lorsque celuici a été informé de sa maladie, de son traitement et des risques qu'il comporte. Le patient capable de discernement décide s'il veut être traité ou non; il est en droit par consequent de faire interrompre la traitement. Cela étant, la base juridique pour appliquer des mesures therapeutiques que le patient ne desire plus fait défaut. Dans ce cas, et conformement au désir du patient, le médecin doit se contenter d'administrer des analgésiques ou de procéder à quelque traitement limité, sans qu'il puisse être rendu responsable juridequement. Fait règle le principe: 'Voluntas aegroti suprema lex esto'.

(2) Si le malade condamné n'est plus capable de discernement et ne peut donc plus exprimer sa volonté (ainsi par exemple le patient inconscient), le devoir du médecin est determiné sur le plan du droit civil par les règles de la 'gestion d'affaires' (C.O. art 419 sq.). La volonté présumée du patient doit dicter les mesures thérapeutiques. Cette volonté ne doit pas être interpretée sans autre dans le sens d'une prolongation des souffrances. L'application des mesures medicales peut au contraire ne plus etre indiquée, en raison du respect du à la personnalité du mourant. Si cette condition est remplie, le medecin peut se justifier sur le plan pénal en invoquant un motif correspondant à la gestion sans mandat ou 'gestion d'affaires'.

(3) Une déclaration écrite antérieure du patient, par laquelle il renonce à toute prolongation artificielle de sa vie, peut être un indice important pour établir quelle est sa volonté. Mais ce qui compte, c'est la volonté présumée actuelle, laquelle ne peut être établie que par une appreciation soigneuse de toutes les circonstances. Du fait déjà qu'elle peut être retirée en tout temps, la déclaration antérieure ne lie pas le médecin. On doit donc toujours se demander si le patient, à l'instant considéré, révoquerait ou non sa decision.

(4) Les proches du patient doivent être entendus. (En règle générale, les proches sont les parents les plus rapprochés du patient; d'autres personnes peuvent eventuellement être considérées comme des proches). Mais la décision dernière, juridiquement, appartient au medécin. Quand le patient est mineur ou interdit, le traitement ne doit être ni réduit ni suspendu à l'encontre de la volonté des parents ou du tuteur.

\section{(v) Abortion}

Abortion also involves the right to life. Subsections (1) and (2) of section 251 of the Criminal Code punish abortion unless performed in accordance with subsections (3) to (6). In cases where abortion is licit, the pregnant woman's consent is still necessary unless it is an emergency situation. ${ }^{137}$ Consent to an abortion outside these sections is null and of no effect as its object is illicit and therefore against public policy. A majority of the Supreme Court of Canada has also held that section 45 of the Criminal Code is not available as a defence to a charge under subsections (1) and (2) of section $251 .{ }^{138}$ This view is questionable as there might be some genuine cases where an abortion should take place and there is not enough time to follow the procedures provided by subsections (3) to (6) of section $251 . .^{139}$ Still section 45 may be inadequate since it protects only a person performing a surgical operation, not a woman from her liability under subsection 2 of section 251 .

Since abortion may endanger the woman's life and destroys the unborn child, her consent alone cannot render lawful that which constitutes a danger to life. Subsections (1) and (2) of section 251 protect

137. S. 251(7).

138. Morgentaler v. The Queen, supra, n. 100. The case also deals with the defence of necessity apart from 8.45 . 139. Id., per Laskin C.J.C., dissenting, at $474-476$ (C.C.C.). 
not only the woman's right to life but also the fetus and society in general. ${ }^{139 a}$ This is why consent cannot render licit an act that is likely to destroy the right of a passive subject, namely the fetus. It is only where abortion is permitted by the Criminal Code that the woman's consent is a valid defence to a charge of assault against the physician.

When abortion is prohibited, the same penalty is applicable whether or not the pregnant woman gives her consent.

It is interesting to note that contrary to the situation in the case of suicide, self abortion is also punishable. ${ }^{140}$ The reason for this rule is that there are two potential victims involved, the pregnant woman and the unborn child.

In some countries, when the woman did not consent to the abortion, the physician is punished more severely. The consent given by the woman may also be punishable as such. In Canada, this seems to be implied by the wording of subsection (2) of section 251 which uses the words "permits any means to be used ....".

\section{(vi) Research Involving Pregnant Women, Fetuses and in vitro Fertilization}

Research, development or demonstration activity should not be conducted on a nonviable fetus ex utero if it were of itself to terminate heart beat and respiration. If such experiments were to be allowed in other situations, they should be consented to by the pregnant woman with the participation of a protection committee. ${ }^{141}$

At the present time, the law generally does not distinguish between viability and nonviability after birth. Full protection as a person is given, notwithstanding that immaturity may preclude the nonviable fetus from having an independent existence. However, legal distinctions might be made on that basis. ${ }^{142}$

With respect to consent, the same rules should apply for therapeutic research on the viable fetus as for such research on an infant. For nontherapeutic research on the nonviable fetus, judicial review might be appropriate. Where a premature infant who has the capacity to sustain heart beat and respiration is involved, the rules applicable to research on children are relevant. ${ }^{143}$

In the case of research involving pregnant women or fetuses in utero the rules relating to abortion may be applicable if as a result of the procedures, a miscarriage takes place. Otherwise, assurances should be obtained that such research will not likely harm the fetus. The consent of both prospective legal parents should also be obtained when reasonably possible especially where a viable fetus is involved. However, since a mother may seek an abortion of a viable fetus because it endangers her health, it may be improper to obtain her consent. In such a case it might be advisable to appoint a guardian for the viable fetus prior to the

\footnotetext{
139a. Compare Weiler, Catton, The Unborn Child in Canadian Law (1976), 14 Osgoode Hall L.J. 643 at 647. 140. Criminal Code, s. 251(2).

141. In U.S. see Department of Health. Education, and Welfare, Protection of Human Subjects, Policies and Procedures, Federal Register, Vol. 40, No. 154, Aug. 8, 1975, p. 33526; 45 F.R.C., \$ 46, 201-211. See Reback, Fetal Experimentation: Moral, Legal and Medical Implications (1974), 26 Stanford L. Rev. 1191; Martin. Ethical Standards for Fetal Experimentation (1974-75), 43 Fordham L. Rev. 547; and Roe v. Wade (1973), 410 U.S. 113,93 S.Ct. 705.
}

142. See Criminal Code, 8. 206.

143. See infra. 
abortion so as not to inhibit procedures designed to save the fetus' life. ${ }^{144}$ Questions may be raised regarding the ethical validity of consent by a pregnant woman on behalf of a fetus for its inclusion in a research activity of no benefit to that fetus, especially if the woman has already decided to terminate her pregnancy.

Where research involves in vitro fertilization it should be approved by an ethical advisory board.

In conclusion, it is of interest to quote the Regulations adopted by the United States Department of Health, Education and Welfare: ${ }^{145}$

Activities directed toward pregnant women as subjects.

(a) No pregnant women may be involved as a subject in an activity covered by this subpart unless: (1) The purpose of the activity is to meet the health needs of the mother and the fetus will be placed at risk only to the minimum extent necessary to meet such needs, or (2) the risk to the fetus is minimal.

(b) An activity permitted under paragraph (a) of this section may be conducted only if the mother and father are legally competent and have given their informed consent after having been fully informed regarding possible impact on the fetus, except that the father's informed consent need not be secured if: (1) The purpose of the activity is to meet the health needs of the mother; (2) his identity or whereabouts cannot reasonably be ascertained; (3) he is not reasonably available; or (4) the pregnancy resulted from rape.

Activities directed toward fetuses in utero as subjects.

(a) No fetus in utero may be involved as a subject in any activity covered by this subpart unless: (1) The purpose of the activity is to meet the health needs of the particular fetus and the fetus will be placed at risk only to the minimum extent necessary to meet such needs, or (2) the risk to the fetus imposed by the research is minimal and the purpose of the activity is the development of important biomedical knowledge which cannot be obtained by other means.

(b) An activity permitted under paragraph (a) of this section may be conducted only if the mother and father are legally competent and have given their informed consent, except that the father's consent need not be secured if: (1) His identity or whereabouts cannot reasonably be ascertained, (2) he is not reasonably available, (3) the pregnancy resulted from rape.

Activities directed toward fetuses ex utero, including nonviable fetuses, as subjects.

(a) No fetus ex utero may be involved as a subject in an activity covered by this subpart until it has been ascertained whether the particular fetus is viable, unless: (1) There will be no added risk to the fetus resulting from the activity, and (2) the purpose of the activity is the development of important biomedical knowledge which cannot be obtained by other means.

(b) No nonviable fetus may be involved as a subject in an activity covered by this subpart unless: (1) Vital functions of the fetus will not be artificially maintained except where the purpose of the activity is to develop new methods for enabling fetuses to survive to the point of viability, (2) experimental activities which of themselves would terminate the heart beat or respiration of the fetus will not be employed, and (3) the purpose of the activity is the development of important biomedical knowledge which cannot be obtained by other means.

(c) In the event the fetus ex utero is found to be viable, it may be included as a subject in the activity only to the extent permitted by and in accordance with the requirements of other subparts of this part.

(d) An activity permitted under paragraph (a) or (b) of this section may be conducted only if the mother and father are legally competent and have given their informed consent, except that the father's informed consent need not be secured if: (1) his identity or whereabouts cannot reasonably be ascertained, (2) he is not reasonably available, or (3) the pregnancy resulted from rape.

144. Note that in some countries interests of the fetus in utero are protected by both the criminal law and the civil law. In the U.S.A. many states have statutes dealing with fetal experimentation. For a survey see Reback, supra, n. 141.

145. See supra, n. 131, \& 46.207 to 209. 


\section{(B) The Right to Physical and Mental Integrity}

\section{Introduction}

In our Western society, it is well established that each individual has the right to the integrity of his body and mind which must not be injured by others. This is a fundamental right that has been enforced by the courts. However, why should an individual not be able to validly dispose of this right by consenting to be injured as long as no harm is done to others? In other words, may the right to physical and mental integrity be legally infringed? As noted previously, self-inflicted injury is generally not punished by the penal law since the offender and the victim are the same person. Why should the solution be different when the injury is inflicted by another but with the victim's consent?

In general, it has been recognized that an individual is free to do as he pleases with his body and no offence is committed when he requests another to infringe his right to physical and mental integrity. However, when the social order is disturbed by such infringement, a criminal offence may be committed. It all depends upon whether or not the State has an immediate and direct interest in the preservation of the physical or mental integrity of such individual. Are there any limitations imposed upon the power to waive the right to physical and mental integrity?

As noted previously, the basic Canadian legislative texts ${ }^{146}$ deal with voluntary harm. Yet, even in the case of voluntary harm liability may still exist.

Men living in society have certain social obligations. To consent to being injured may harm society. Although, today, an individual is given great freedom with respect to his body, there should be some limits imposed upon this freedom. The State must protect the physical and mental integrity of people who are a source of wealth, for instance for economic reasons, for defence purposes and so on. Where the State has a direct and immediate interest in the physical and mental integrity of the victim, consent should be irrelevant.

In principle, the right to physical and mental integrity should not be capable of being waived. However, there must, of necessity, be some exceptions to this principle especially in the medical field and with respect to sports. ${ }^{147}$ In Canada and in England, it has been stated and restated over and over that everyone has a right to consent to the infliction upon himself of bodily harm not amounting to maim. Thus, the Canadian Criminal Code recognizes the validity of consent in the case of assault.148 The correct approach would seem to be that consent is effective provided the injury is not too serious. Consent to be effective must not be against public policy. If the risk of injury is too serious, consent if given is against public policy and of no effect.

The piercing of ears, tattooing, circumcision, blood transfusion, defloration of virginity, removal of skin, cutting of hair, nails, beard, esthetic surgery, and some medical experiments are certainly not against public policy. Only where the resulting injury could be very serious would consent to such injury be against public policy. When the Criminal Code mentions consent, it must mean consent that is not against public policy, whose effect is not illicit.

146. Criminal Code, ss. 244.246.

147. For a good example see Indian Penal Code, s. 87.

148. Criminal Code, s. 244. 
In the case of a criminal offence due to the negligence of the actor, consent should also be a good defence but not on the private law side if it amounts to malpractice..$^{149}$

When treating or operating upon a patient a physician or surgeon infringes the patient's physical or mental integrity. Thus, a charge of assault is always possible. However, consent or the doctrine of emergency-necessity prevents the act from being a criminal assault or civil battery. ${ }^{150}$ Should the rules be different where the act of the physician or surgeon is not done for therapeutic reasons but for esthetic or experimental purposes? Furthermore, in the case of castration, sterilization or change of sex, is the act against public policy so that consent to it becomes illicit?151 These are some of the questions that will be analyzed in the following sections.

\section{Therapeutic Treatment}

The criminal law seems quite clear in the case of therapeutic treatment which is for the benefit of the patient. Such treatment does not constitute an assault if consent to it has been validly given.152 The act of the surgeon or physician is justified and licit as public policy is not against therapeutic treatment. In fact, the State has a direct interest in having its citizens properly treated and restored to good health. Furthermore, when the patient asks the physician to treat him, he is deemed to accept all the consequences that may result from such treatment.

It could also be argued that admission to the practice of medicine which is sanctioned by the law gives immunity to the physician. The physician must act for therapeutic reasons, he must also be a physician and licenced to practice in the province where the treatment takes place. Consent given to a layman would not be effective as only physicians are allowed to treat patients. ${ }^{153}$

If consent is given to a therapeutic treatment, the physician cannot experiment with the patient since by doing so he would exceed the consent that has been given to him. The therapeutic aspect of the treatment or operation is the consideration for consent. This consideration is illicit if the physician's act is not therapeutic.

The physician must also act in conformity with sound medical practice without imprudence or negligence. As noted previously, the consent must be "informed" as the patient must be made aware of the treatment and of its consequences. ${ }^{154}$

When the patient consents to an operation, it does not automatically imply that the surgeon is authorized to perform further surgical procedures if needed as a result of what he discovers during the operation. Immunity from prosecution exists if the best interests of his patient's health and possibly life required him to perform further surgical procedures. ${ }^{155}$ If the "informed" consent included the possibility of such procedures, the surgeon should be protected. The justification for the physician's immunity from the criminal law is consent validly given. If

149. Id., s. 202. As noted previously consent is not the equivalent of an exculpatory clause.

150. Id., 8s. 224, 198, 45.

151. See Bravery v. Bravery, [1954] 3 All E.R. 59, per Denning L.J. (C.A.).

152. Criminal Code, 8. 244.

153. See, however, id., s. 45.

154. See supra.

155. Compare Marshall v. Curry, [1933] 3 D.L.R. 260, 60 C.C.C. 136 (N.S.S.C.) to Murray v. McMurchy, [1949| 2 D.L.R. 442, [1949] 1 W.W.R. 989 (B.C.S.C.). 
the patient cannot consent his legal representatives will do so for him. This raises the question whether minors or other legally incompetent persons should be consulted and their consent obtained sometimes in addition to or without that of their legal representatives.

\section{(a) Minors, Mental Patients}

Normally, parental consent is required by law for the performance of non-emergency medical procedures on minors. However, today, the courts of some provinces and in most of the United States have held that a minor approaching the age of majority may give his own consent if he has the intellectual capacity to fully appreciate the nature and consequences of a medical procedure performed for his benefit. ${ }^{156}$ This is called the "mature minor" exception. For the purposes of consent to medical treatment, the age of consent and the age of majority are not necessarily the same. The test is whether the patient is old enough to be able to appreciate the nature of the treatment and come to a reasonable decision. ${ }^{157}$

American legislatures have also adopted laws which permit any unemancipated minor of sufficient intelligence to understand and appreciate the consequences of the proposed surgical or medical treatment or procedures, to consent to beneficial therapeutic medical procedures. ${ }^{158}$ Since the test adopted depends upon the maturity of the individual minor patient, the range for effective consent may vary between the ages of fourteen and eighteen, although if one were to follow section 13 of the Criminal Code by analogy, the minimum age could be lowered to seven. that:

In England section 8 of the Family Law Reform Act $1969^{159}$ provides

8(1) The consent of a minor who has attained the age of sixteen years to any surgical, medical or dental treatment which, in the absence of consent, would constitute a trespass to his person, shall be as effective as it would be if he were of full age; and where a minor has by virtue of this section given an effective consent to any treatment it shall not be necessary to obtain any consent for it from his parent or guardian.

(2) In this section "surgical, medical or dental treatment" includes any procedure undertaken for the purposes of diagnosis, and this section applies to any procedure (including, in particular, the administration of an anaesthetic) which is ancillary to any treatment as it applies to that treatment.

(3) Nothing in this section shall be construed as making ineffective any consent which would have been effective if this section had not been enacted.

The capacity of a child over sixteen years depends entirely upon his ability to understand the nature and effects of the procedures undertaken.

Section $8(3)$ is a statutory recognition that at common law it may be possible for a minor under sixteen to validly consent and expressly reserves that right for the underage minor.

156. Nathan, Medical Negligence 176 (1957); Johnston v. Wellesley Hospital, supra, n. 38.

157. Sharpe, The Minor Transplant Donor (1975), 7 Ottawa L. Rev. 85; Skegx. Consent to Medical Procedures on Minors (1973), 36 Mod. L. Rev. 370. Not discussed here are the emergency exception, since it is of a general nature, i.e. no consent is required in the case of an emergency; or the emancipated minor exception, i.e., an emancipated minor is one who is treated as an adult by reason of an agreement with or conduct by the parents that establishes the minor's independence from them. Such minor may consent to medical treatment: or the best interests of the child exception which involves a conflict between the right of the parents to withhold consent and the power of the State to order the medical treatment as parens patriae.

158. E.g., Miss. Code Ann. \$ $7129-7181$ (1966); Pilpel, Minor's Rights to Medical Care (1972), 35 Albany L. Rev. 462. In general see Wilkins, Children's Rights: Removing the Parental Consent Barrier to Medical Treatment of Minors, [1975] Ariz. St. L.J. 31; Tompkins, Health Care for Minors: The Right to Consent (1974-76), 40 Sask. L. Rev. 41: Crepeau, Le consentement du mineur en matiere de soins et traitements medicaux ou chiruricaux selon le droit civil canadien (1974), 52 Can. Bar Rev. 247; Mayrand, supra, n. 23 at 52 et seq.; Wadlington, Minors and Health Care: The Age of Consent (1973), 11 Osgoode Hall L.J. 115.

159. C. 46. 
In Ontario a Regulation passed ${ }^{160}$ pursuant to the Public Hospitals Act ${ }^{161}$ permits a person sixteen years of age or older to give a valid consent to a surgical operation, diagnostic test or a form of medical treatment without parental consent or determination of his capacity to fully appreciate the nature or consequences of the proposed form of treatment, so long as the physician sees him in certain public hospitals and that is the place where the treatment is administered. The regulation also limits the operations of the emergency exception to life-threatening situations. ${ }^{162}$ In Quebec article 36 of the Public Health Protection Act provides that: 163

An establishment or a physician may provide the care and treatment required by the state of health of a minor fourteen years of age or older with his consent without being required to obtain the consent of the person having paternal authority; the establishment or the physician must however inform the person having paternal authority in the case where the minor is sheltered for more than twelve hours, or of extended treatment. Where a minor is under fourteen years of age, the consent of the person having paternal authority must be obtained; however, if that consent cannot be obtained or where refusal by the person having paternal authority is not justified in the child's best interest, a judge of the Supreme Court may authorize the care or treatment.

In the case of a minor under the age of fourteen his parents can not force upon him a treatment that is not for his benefit. Furthermore, if the parents refuse treatment, it can be authorized by the courts.

When the life of the minor is in danger parental consent or court authorization is not required: ${ }^{164}$

An establishment or a physician shall see that care or treatment is provided to every person in danger of death; if the person is a minor, the consent of the person having paternal authority shall not be required.

As far as the criminal law is concerned in the absence of statutory provisions to the contrary, there is no reason to believe that minors are in a position different from that of adults with respect to consent to medical treatment of a therapeutic nature.

To conclude, it would seem reasonable to maintain that consent to medical therapeutic treatment should be entirely dependent upon the patient's capacity to understand that to which he is consenting and to give an "informed" consent to it. Age should be an irrelevant consideration to a determination of the validity of a consent whether for private law or criminal law purposes. Where the minor is unable to give an "informed" consent his parents or guardian would consent on his behalf provided the treatment is for the benefit of the minor. Should they refuse, court authorization would be sought except in the case of an emergency.

It is suggested that the provinces should adopt the Uniform Medical Consent of Minors Act ${ }^{165}$ which provides that:

1. In this Act 'medical treatment' includes

(a) surgical and dental treatment,

(b) any procedure undertaken for the purpose of diagnosis,

160. R.R.O., 1970, R. 729 as am. 100/74, ss. 49, 49(a). Also McLellan, Jehovah's Witnesses and Child Protection Legislation: The Right to Refuse Medical Consent (1977), 1 Leg. Med. Q. 37.

161. R.S.O. 1970 , c. 378 as am.

162. See also Infants Act, R.S.B.C. 1960, c. 193, s. 23. Uniform Medical Consent of Minors Act 1975, Proceedings Uniform Law Conference of Aanada 162. Some Ontario Hospitals require parental consent for abortion up to the age of eighteen. It has also been questioned whether a sixteen year old can consent to a non-therapeutic irreversible procedure such as contraceptive sterilization.

163. L.Q., 1972, c. 42.

164. Id. art. 32.

165. 1974 Proceedings Uniform Law Conference 162 
(c) any procedure undertaken for the purpose of preventing any disease or ailment,

(d) any procedure undertaken for the purpose of preventing pregnancy, and

(e) any procedure that is ancillary to any treatment as it applies to that treatment.

2. The law respecting consent to medical treatment of persons who have attained the age of majority applies, in all respects, to minors, who have attained the age of sixteen years in the same manner as if they had attained the age of majority.

3.(1) The consent to medical treatment of a minor who has not attained the age of sixteen years is as effective as it would be if he had attained the age of majority where, in the opinion of a legally qualified medical practitioner or dentist attending the minor, supported by the written opinion of one other legally qualified medical practitioner or dentist, as the case may be,

(a) the minor is capable of understanding the nature and consequences of the medical treatment, and

(b) the medical treatment and the procedure to be used is in the best interests of the minor and his continuing health and well-being.

(2) The consent of a minor who has not attained the age of sixteen years or of his parent or guardian is not required in relation to medical treatment performed with respect to that minor where

(a) the minor is incapable of understanding the nature and consequences of the medical treatment or, being capable of understanding the nature and consequences of the medical treatment, is incapable of communicating his consent to the medical treatment, and

(b) a legally qualified medical practitioner or dentist attending the minor is of the opinion that the medical treatment is necessary in an emergency to meet imminent risk to the minor's life or health.

4.(1) Where the consent of a parent or guardian to medical treatment of a minor is required by law and is refused or otherwise not obtainable, any person may apply to (insert court as appropriate to the jurisdiction) for an order dispensing with the consent.

(2) The court shall hear the application in a summary manner and may proceed $e x$ parte or otherwise and, where it is satisfied that the withholding of the medical treatment would endanger the life or seriously impair the health of the minor, may by order dispense with the consent of the parent or guardian to such medical treatment as is specified in the order.

5. Where, by or under this Act, the consent of the parent or guardian of a minor to his medical treatment is not required or is dispensed with, the medical treatment does not for the reason that the consent of the parent or guardian was not obtained, constitute a trespass to the person of the minor.

In the case of a mental patient, the person authorized by law to represent him may consent to treatment that is beneficial to the patient. ${ }^{166}$ In the common law provinces where the patient is not under guardianship or in the absence of other legal authorization, it is customary to seek the consent of those able to take legal proceedings, such as a relative or hospital administrator whose powers are confined to consenting to procedures creating little risk of harm.

It is suggested that, as in the case of minors, the mental patient's consent should be sufficient if he is capable of appreciating fully the nature and consequences of a particular operation or of a particular treatment. Otherwise, in the absence of an emergency, consent should be given by a committee especially appointed for this purpose provided the treatment or operation is of therapeutic nature.

\section{(b) Absence of Consent}

When the patient has given no consent or refuses to give his consent to treatment or to an operation of a therapeutic nature that is for his benefit, no protection is given to the physician or surgeon ${ }^{167}$ unless, in the case of 
a surgical operation an emergency situation exists and the operation is for the benefit of the patient. 168 In emergency cases, it is also presumed that everyone desires medical treatment. The patient's consent is said to be implied although it is not "informed". Thus, liability is still possible.

Does the treatment without consent or upon consent that is null and void, by ingestion of a prescribed drug constitute a criminal assault? It does not appear to be so unless force is used or it was against the will of a patient who took the drug.

It is submitted that the doctrine of necessity should exonerate a physician or surgeon in cases where the patient opposes the therapeutic treatment or operation especially when children or pregnant women are involved and lack of treatment or operation would endanger the patient's life or that of the unborn child. ${ }^{169}$ In the United States in such cases, some courts have substituted their consent for that of the adult patient or legal representative of a minor or incompetent patient. 170 Judicial interference in the face of patient opposition should certainly be countenanced in cases where the life of the patient is at stake. ${ }^{171}$ It is also suggested that non-intentional injury could be criminal negligence $e^{172}$ in the absence of malpractice where consent was not given and no emergency existed. To some extent sections 204 and 244 of the Criminal Code overlap.

\section{(c) Proposal}

It may be advisable to have a section in the Criminal Code dealing with the protection of the individual that would make a distinction between assault where the treatment is administered or the operation performed against the express wishes of the patient or his representatives and the case where consent was not obtained at all. The text could also deal with the conditions of validity (for instance, the requirements of "informed" consent) of such consent and declare that no civil and criminal liability exists when an operation or treatment takes place in an emergency without the patient's consent and it is for his benefit. This text would replace or modify sections 45,198 , and 244 of the Criminal Code.

\section{Therapeutic Treatment in Which Clinical Research}

\section{Is Combined with Professional Care}

We are concerned here with the individual therapeutic experiment or innovative therapy taking place when a critically ill patient is not responding to the standard or prescribed treatment for his disease. Frequently, such innovative therapy involves a patient suffering from a fatal disease.

As a last resort, the physician will administer the patient an untried or even potentially dangerous drug, or attempt a new type of operation, for instance a heart transplant, knowing that the chances of success may be very slim. In these cases, the experiment or innovative therapy may advance the state of medicine without further jeopardizing the patient's life. Since the prime purpose of the experiment or innovative therapy is to save the patient's life, it would seem that this therapeutic aspect should not modify the traditional relationship existing between the patient's

168. Id. 88. $45,188$.

169. In general see Skegg, A Justification for Medical Procedures Performed Without Consent (1974), 90 L.Q. Rev. 512.

170. See, e.g., Application of the President of Georgetown College (1964), 201 A. 2d 537 (N.J. Sup. Ct.). Contra: Re Brooks Estate (1965), 205 N.E. 2d 435 (Ill. Sup. Ct.).

171. See also Raleigh-Fitkin Memorial Hospital v. Anderson (1964), 201 A. 2 d 537 (N.J. Sup. Ct.).

172. Criminal Code, 8s. 202, 203, 204. 
faith and the physician's fiduciary duty. The same rules should be applied here as in the case of customary therapy. An "informed" consent must be obtained from the patient. The fact that the new drug or the new type of operation may be life-saving or of no value at all should not modify this conclusion as long as the patient is informed of the risks involved and of the chances of success.

For instance, in the case of a transplantation operation, the type of risk involved and the novelty of the operation should have a bearing on the completeness of the disclosure required. In order for the consent to be knowing and voluntary, the recipient is entitled to full disclosure of all possible serious direct and collateral hazards.

Of course, the surgeon's duty does not mean that he must apprise the patient of each infinitestimal or speculative element making up such risks, as it would often be psychologically harmful to frighten him with too remote possibilities. Actually, in the light of the possible undesirable effects of disclosure of some medical or surgical risks on a number of patients, it might be better to treat disclosure as a question of negligence involving professional standards of conduct only. This approach, however, should not be applied to experimentation. Furthermore, today, the trend in standard of disclosure is clearly away from professional standards to lay ones.

Innovative therapy may pose known risks as well as unknown ones. If the physician fails to disclose to his patient a known material risk of the proposed innovative therapy he may be civilly or criminally liable if such a risk materializes. ${ }^{173}$ If on the other hand, the general nature of the treatment or operation including the fact that it is experimental is understood and the collateral risks fully disclosed, no assault charge could be laid against the physician under section 244 of the Criminal Code. However, consent to reckless experimenentation should be against public policy even if its purpose were to seek a cure. This would include auto-experimentation where the investigator takes unwarranted risks with his own health in pursuit of his investigation. The effect of the patient's consent would depend on the propriety of using the innovative therapy in the first place. For instance, homoplastic transplants are not against public policy as long as they are performed within the limits set by the various provincial Human Tissue Acts or the provisions of the Quebec Civil Code. Blood transfusions are also legal. In both cases consent must be obtained. On the other hand, heteroplastic transplants may have to be prohibited even where the patient's consent has been obtained as they have never been successful.

Where the use of an innovative procedure is negligent in light of its known and significant collateral risks, the physician has breached his duty of care to the patient in the manner of treatment. Thus, the patient's consent to disclosed risks becomes irrelevant. In other words, the use of an innovative therapy should constitute good medical practice under the circumstances. The patient's consent should not be a complete answer to every problem posed by innovative therapy. ${ }^{174}$ For obvious reasons a physician has no legal duty to disclose to a patient risks which he does not know or should not know. However, if the innovative therapy raises

173. See Declaration of Helsinki 1964 as revised in Tokyo in 1975, II, 3, Medical Research Combined with Professional Care. Also Cryderman v. Ringrose, supra, n. 27.

174. But see Ethical Guidelines for Clinical Investigation by the American Medical Association and Beecher, Consent in Clinical Experimentation: Myths and Reality (1966), 195 J.A.M.A. 34. Also Cryderman v. Ringrose, supra, n. 27. 
too many unanswered questions, it would be unreasonable for a physician to go ahead with the therapy even if the patient had consented to unknown risks.

Children and prisoners do not seem to present particular problems when innovative therapy is applied to them. This is not necessarily the case with respect to persons affected by behavioural disturbances. Should the use of new techniques call for the application of special rules on the ground that it is difficult to obtain an adequately informed consent from the patient, his parents or guardian? Several questions readily come to mind: is the patient himself competent to consent when he allegedly has some neurological or psychological defect necessitating the treatment? May a third party consent for an incompetent if the potential risks of the treatment outweigh the probable and possible benefits to the subject? Do the numerous unknowns inherent in the new technique prevent the physician or surgeon from adequately informing and advising the patient or his representatives as "informed" consent requires?

\section{(a) Psychosurgery}

Experimental surgical alteration of behaviour, called psychosurgery, which involves the removal or destruction of tissue and nerve cells in the brain deemed to be responsible for the undesirable behaviour, ${ }^{175}$ although still at the experimental stage, is generally considered as primarily therapeutic. However, if healthy or non-affected brain tissue or nerve cells are also destroyed they will not regenerate, for the effect of psychosurgery is irreversible. In most cases where psychosurgery is used, mental patients do not respond to drug therapy or other generally accepted modes of psychiatric treatment. It would seem that if the new technique is subject to serious controversy as to its potential curative effect, it should only be authorized in extreme cases and with great caution. ${ }^{176}$

In the United States of America in Kaimowitz v. Michigan Department of Mental Health ${ }^{177}$ the court was of the opinion that psychosurgery should never be performed on an involuntarily confined person. ${ }^{178}$

The court said: ${ }^{179}$

Experimental psychosurgery, which is irreversible and intrusive, often leads to the blunting of emotions, the deadening of memory, the reduction of affect, and limits the ability to generate new ideas. Its potential for injury to the creativity of the individual is great, and can impinge upon the right of the individual to be free from interference with his mental processes.

In the court's view three elements are necessary for consent: (1) competence, (2) knowledge, and (3) voluntariness. The court also pointed out that mental patients cannot reason as equals with physicians and mental hospital administrators. A patient involuntarily confined may not be able to give a voluntary consent because of the real or imagined pressures on him. The court even accepted the view that such duress may

175. Brain surgery involves the removal of diseased brain cells to relieve organic disorders such as tumors.

176. See Heldman, Behqvior Modification and Other Legal Imbroglios of Human Experimentation (1974.75), 52 J. of Urban L. 157; Zwerdling, Informed Consent and the Mental Patient: California Recognizes a Mental Patient's Right to Refuse Psychosurgery and Shock Treatment (1974-75), 15 Santa Clara Lawyer 725; Spoonhour, Psychosurgery and Informed consent (1974), 26 U. of Florida L. Rev. 432; Sitnick, Major Tranquilizers in Prison: Drug Therapy and the Unconsenting Inmate (1975), 11 Willamette L.J. 378; Mearns, Law and the Physical Control of the Mind: Experimentation in Psychosurgery (1975), 25 Case Western L. Rev. 565.

177. (1973), 42 U.S.L.W. 2063 (Mich.); notes Fabri (1973), 50 Chi. Kent L. Rev. 526; Gold (1974), 4 N.Y.U. Rev. of L. \& Social Change 207.

178. The patient was an alleged murderer and rapist confined to a state hospital because of his homicidal rages.

179. Supra, n. 177 at 2064. 
extend to one voluntarily confined.180 As long as the experimental treatment has such proportionately high risks compared to the benefits to the patient, no consent could ever be adequately "informed".

\section{(b) Adversive Therapy}

Adversive therapeutic techniques have also been the subject of criticism by the American courts especially when prisoners are involved. ${ }^{181}$

To conclude, it would seem that in therapeutic experiments in which clinical research is combined with professional care, additional protection is needed for those mentally infirm especially if they are institutionalized since they may lack either the competence or the autonomy or both to give an "informed" consent. Furthermore whether or not the patient has been determined to be legally incompetent should not be the sole criterion used in determining whether or not he is able to give an "informed" consent.

In California, in response to the need for regulating the use of dangerous and controversial innovative treatment on patients without their consent, the legislature has adopted a law which provides that mental patients have the right to choose whether to submit to psychosurgery or shock treatment in California mental institutions. ${ }^{182}$ Before a physician can administer these procedures, the patient must "knowingly and intelligently, without duress or coercion, manifest consent to the treatment". Prior to seeking the patient's consent the physician must give him: ${ }^{183}$

1. an explanation of the procedures used in performing the treatment;

2. an explanation of the nature and seriousness of the patient's disorder;

3. an explanation of the patient's right to revoke consent before or during the procedure;

4. an explanation of reasonable alternative therapies;

5. an explanation of uncertainties associated with the treatment; and

6. an explanation of the hazards associated with the procedures.

To be able to accept psychosurgery or shock treatment, the patient must be capable of giving an "informed" consent. Capacity to consent is determined not by a superior court but by a review committee comprised of physicians. If the committee determines that the patient cannot give an informed consent to psychosurgery, such procedure cannot take place. However, the committee can authorize shock treatment over the patient's objections if it determines that such treatment is necessary.

In view of the serious risks involved in these techniques, it would seem that the issue of capacity to consent should be determined in the same manner as that used to determine mental capacity during a commitment or guardianship proceeding conducted by a court.

\section{Non-Therapeutic, Non-Experimental Treatment}

(a) With or Without Benefit to the Patient

In principle, a treatment or operation which is not intended to improve the physical or mental health of a patient should be prohibited. His

180. See also Medical News (1973), 225 J.A.M.A. 1035, 1036, 1044, where two cases are reported: one where the court stayed psychosurgery on the ground of the patient's inability to give consent; and the other where the plaintiff was held not to have been adequately informed of the risk in the procedure.

181. See, e.g., Mackey v. Procunier (1973), 477 F. 2d 877 (9th Cir.); Knecht v. Gillman (1973), 488 F. $2 \mathrm{~d} 1163$ (8th Cir.).

182. Cal. Stats (1974), c. 1534, at 4328 (West Legislative Service).

183. Cal. Welf. \& Inst'ns Code, $§ 5326.3$ (West Supp. 1975). 
consent should null and void for illicit cause or consideration and thus contrary to public policy. However, exceptions to this principle should be recognized. For instance, esthetic or cosmetic treatment or surgery, ${ }^{184}$ the purpose of which is to beautify the patient, although not intended to improve his physical health, often has the effect of improving his mental health. For this reason, it is of a beneficial nature and, provided an informed consent has been obtained, the procedure should not be prohibited. Where the removal of physical defects is dangerous and threatens the health of the patient, it should not be allowed and the patient's consent should be null and void as contrary to public policy.

A change of sex or surgical transsexualism would seem to be justified for therapeutical reasons only ${ }^{185}$ if its purpose is to cure the patient's psychological disorders as this type of operation often involves serious physical and psychological risks to the patient. 186 The patient must give an informed consent. The physician must explain to him that it is really not possible to alter a person's sex. Only the appearances of sex can be changed. Transsexualism is a matter of public policy which in certain cases should not be affected by consent. Thus, the operation may amount to causing bodily harm. ${ }^{187}$ However, if the operation can prevent the deterioration of the patient's mental health it is therapeutic and consent to it should be effective.

Maiming which is covered by section 228 of the Criminal Code does not seem to take consent into consideration. ${ }^{188}$

\section{Sterilization}

Sexual sterilization is the process whereby a male or female person is deprived of his or her ability to procreate. Sterilization can involve total surgical removal of all or some of the reproductive organs, for instance castration in the male, and removal of the uterus (histerectomy), ovaries or fallopian tubes in the female. A less drastic form of sterilization prevents procreation without the removal of any organs, for instance vasectomy in the male and tubal ligation in the female.

Sterilization can be divided into three types: therapeutic, eugenic and contraceptive. ${ }^{189}$ There can be no doubt that sterilization is legal when performed for therapeutic reasons, provided the patient has given a free and informed consent to the operation. ${ }^{190}$

There is no Canadian legislation or case law directly dealing with this question. In England or Canada all judicial references to the issue of sterilization have been obiter. Thus, in Bravery v. Bravery, ${ }^{191}$ Lord Denning conceded that vasectomy for health or eugenic reasons was permissible, for instance where the wife's health would be endangered by any further pregnancies or where sexual intercourse could result in the

184. See Kelly v. Hazlett, supra, n. 23.

185. Mayrand, supra, n. 23 at 34.

186. See Brent, Some Legal Problems of the Post-operative Transsexual (1972-73), 12 J. of Fam. L. 405; Kouri, Transsexualism in the Province of Quebec (1973), 4 R.D.U.S. 167; Kouri, Certain Legal Aspects of Modern Medicine (1975); also Corbett v. Corbett, [1971] P. 83.

187. Criminal Code, 8. 228.

188. Supra, n. 70.

189. Dickens, Eugenic Recognition in Canadian Law (1975), 13 Osgoode LJ. 556. See also Anonymous, Comments Upon the Law Relating to Abortion and Sterilization (1961), 33 Man. Bar News 38; Black, Abortion and Sterilization (1961), 33 Man. Bar News 38; Oldershaw, Contraception, Abortion and Sterilization (1975); Kouri, Certain Legal Aspects of Modern Medicine (1975).

190. Williams, The Sanctity of Life and the Criminal Law 101 (1958). See also Criminal Code, s. 45. 191. [1945] I W.L.R. 1169, [1954] 3 All E.R. 56 (C.A.). 
transmission of an hereditary disease. However, in his dissenting judgment, his Lordship expressed the view that sterilization for purely contraceptive reasons opens the way to licentiousness. Furthermore, he was of the opinion that if there was no "just cause or excuse" for the operation, it was unlawful even if the man had consented to it. ${ }^{192}$ This opinion carries questionable weight, not only because it is obiter but also because the rest of the court took care to disjoin themselves from it. The court in Bravery, however, seems to recommend that both spouses' consent be obtained prior to sterilization. This view was supported in an Ontario Supreme Court case, which involved a therapeutic sterilization..$^{193}$

Since sterilization, apart from constituting an aggression upon the body of the spouse submitting to the operation, amounts to an infringement of the right to procreation of both spouses, it would seem to be reasonable to require the consent of both parties, especially where the operation is for contraceptive purposes only. There may, however, be special circumstances justifying sterilization of a consenting spouse even in the absence of the other spouse's consent. Furthermore, in many jurisdictions, married persons possess medical autonomy. ${ }^{194}$

By virtue of the dearth of judicial pronouncements on the issue, it is necessary to turn to the Criminal Code for directions. Perhaps the most relevant section is section 45 which has already been discussed in this article. It could be argued that the words "for the benefit of that person" found in the section should be given a wider interpretation than that which they are usually accorded, that is physical benefit. ${ }^{195}$ Can it not be argued that if a couple who cannot afford to have more children choose sterilization as a solution, they are receiving a benefit from the operation? Or the benefit can even be construed as the emotional relief of knowing one need no longer worry about an unwanted pregnancy. Surely, the argument concludes, it is not up to the Criminal Code to legislate that people cannot choose what constitutes a benefit to them.

Another section that could be applied to sterilization is section 228 of the Criminal Code which deals with causing bodily harm with intent, especially maiming.

Maiming is defined as follows:

... to cripple or mutilate in any way, to inflict upon a person any injury which deprives him of the use of any limb or member of the body, or renders him lame or defective in bodily vigor; to inflict bodily injury; to seriously wound or disfigure; disable. ${ }^{196}$

While it is doubtful that this definition would describe a tubal ligation or vasectomy, it could be applied to castration or a medically unnecessary hysterectomy. Since consent is not mentioned in the section, it could be argued that once the intent to maim has been proved, the consent of the victim is irrelevant. However, this requires a brief look at judicial dicta as to when consent renders an illicit act legal.

192. Id. at 1180 (W.L.R.).

193. Chivers and Chivers v. Weaver and McIntyre (1947), unreported, per Kelly J., referred to in Blaier, Sterilization in Canada: Some Legal and Social Considerations (1977, unpublished paper, Osgoode Hall Law School). Cryderman v. Ringrose, supra, n. 27 did not involve the legality of sterilization but the liability of the physician in negligence for performing an experimental sterilization on a patient without sufficiently informing her of the unreliability of this new procedure or of the possible damage to the uterus and unborn child. No reference was made to the consent of the patient's husband. Note that parental consent may not allow sterilization of a minor on eugenic or contraceptive grounds: $\operatorname{Re} D$, [1976] 1 All E.R. 326. In Sparkman v. McFarlin 522 F. 2d 172 (1977), it was held that a judge is not immune for granting a mother's request for the sterilization of her fifteen year old daughter.

194. See e.g., Family Law Reform Act, 1975, S.O., 1975, c. 41, 8. 1(2).

195. See Blaier, supra, n. 193, at 10.

196. Black's Law Dictionary 1131 (4th ed., 1968). 
The most general statement is probably that of Stephen J. in The Queen v. Coney: ${ }^{197}$

The principle as to consent seems to me to be this: When one person is indicted for inflicting personal injury upon another, the consent of the person who sustains the injury is no defence to the person who inflicts the injury, if the injury is of such a nature... that its infliction is injurious to the public as well as to the person injured. 198

It would seem that most maims are contrary to public interest since our society, while emphasizing individual liberty, protects certain fundamental rights, such as bodily integrity. Thus, a man who requests to have his healthy arm cut off will probably find that his consent does not relieve the surgeon from criminal or civil liability. By analogy, the surgical removal of reproductive organs would be against public policy where the State does not favour birth control and encourages the raising of large families. Consent to such an operation would be illegal and void. On the other hand, it could be argued that where a legal question is uncertain, it should always be resolved in favour of individual liberty. ${ }^{199}$ Glanville Williams feels that "where the defendant has no intention to defraud or to make himself a charge upon others, the pain or wound that he chooses to inflict upon himself is not generally a matter of public concern". 200

In 1970, the Canadian Medical Protective Association recommended that sterilization for contraceptive purposes should be a matter to be decided solely by the doctor and the patient involved, as in other cases of non-therapeutic treatment. ${ }^{201}$

If it is argued that sterilization for non-therapeutic purposes is against public policy, it does not seem possible, in accordance with the "clean hands" doctrine of equity, to permit a sterilized patient who has "consented" to sterilization to sue his doctor for damages. The restriction would have to be criminally enforced by the police and prosecuted by Crown attorneys, which would in turn call for a Criminal Code section clearly making sterilization illegal. Since there is nothing in the Criminal Code expressly forbidding sterilization, it can be argued that it is legal on the assumption that everything is legal unless forbidden by law. There can also be little doubt that any sterilization without the express consent of the patient would open the way to criminal prosecution as well as civil action.

Eugenic sterilization was once provided for in British Columbia and Alberta ${ }^{202}$ in the case of mentally retarded people as well as those likely to transmit certain hereditary diseases. Both Acts have now been repealed. ${ }^{203}$ It is interesting to note that the inmate consent was still required by the British Columbia Act which in section 6 provided that:

The operation directed by the order of the Board of Eugenics in any case shall not be performed unless the inmate has consented thereto in writing, if in the opinion of the Board the inmate is capable of giving consent, or, if in the opinion of the board the inmate is not capable of giving consent, unless the husband or wife of the inmate or, in

197. (1882), 8 Q.B.D. 534.

198. Id. at 549 .

199. Williams, supra, n. 190 at 106.

200. Williams, Consent and Public Policy, [1962] Cr. L. Rev. 74 at 155.

201. Blaier, supra, n. 193 at 10.

202. R.S.B.C. 1960, c. 353; R.S.A. 1970, c. 341. For further discussion, see Blaier, supra, n. 193, as well as McWhirter and Weijer, The Alberta Sterilization Act: A Genetic Critique (1969), 19 U.T.L.J. 424.

203. The Sterilization Repeal Act, S.A. 1972. c. 87; The Sterilization Repeal Act, S.B.C. 1973, c. 79; In New Zealand see Contraception, Sterilization and Abortion Act 1977, Bill No. 57-1, s8. 7-13, which provides for the sterilization by court order of any person who is mentally subnormal. 
case the inmate is unmarried, the parent or guardian of the inmate has consented thereto in writing, or, in case the inmate has no husband, wife, parent, or guardian resident in the Province, the Provincial Secretary has consented thereto in writing.

With respect to a mentally defective person, sterilization should be lawful if it is done for his benefit and with the consent of his parent or guardian. ${ }^{203 a}$. However, a merely involuntary eugenic sterilization should be ruled out.

Sterilization must be voluntary. Thus, in the case of the prisoners, ${ }^{204}$ they should not be forced or bribed to consent. For instance, prisoners sentenced for indeterminate terms or for life may not be capable of completely free choice since their range of options is severely restricted by the indeterminate or life sentences. Where there is a possibility of early release, does coercion nullify free consent? A reasonable view would be that free consent could be obtained even in total institutions. Since in some jurisdictions the law allows certain choices made under the pressure of avoiding or reducing incarceration, as in the case of plea bargaining, there is no reason why a prisoner could not give a valid consent. However, one should not allow someone to buy his freedom by cutting such an important part of himself.

\section{(b) Without Benefit to the Patient But for the Direct Benefit of Another}

An operation upon a healthy individual with a view to effecting eventually the cure of another person is certainly licit. Blood transfusions as well as the grafting of organs, skin or limbs of a healthy individual upon an ailing patient are licit provided such operations do not imperil the life or health of the donor. Of course the operation must be performed in accordance with scientifically approved methods as in the case of therapeutic operations and the donor's "informed" consent must have been freely given. No consent can justify the transplant of an organ without which the donor cannot live (for instance, the heart) irrespective of his motives. Nor should it be possible to transplant organs such as sexual glands if such an operation is considered against public policy. In the case of a live donor it is doubtful that the doctrine of emergency ${ }^{205}$ or necessity could ever be applied.

As in therapeutic situations, failure to disclose the risks, known to the surgeon, invalidates the donor's consent. Thus, even though the donor has signed a written consent, it might not exonerate the surgeon from civil or criminal liability if it is possible to prove that he withheld facts that were necessary to form the basis of an intelligent consent to the transplant. The surgeon must not minimize the known dangers of the operation in order to induce his patient's consent. However, in discussing the element of risk involved in the transplantation, the surgeon has such discretion as is consistent with the full disclosure of facts necessary to an informed consent.

A transplant operation is especially serious for the live donor who should be given adequate explanations to help him decide whether he would rather forego surgery than submit to it. There is always the danger that an overly enthusiastic transplant team may not disclose all that is relevant to the operation in order to prevent the prospective donor from

203a. Note that parental consent may not allow sterilization of a minor on eugenic or contraceptive grounds: Re $D$. [1976] 1 All E.R. 326. By analogy, it may be argued that in the case of a mentally defective person, parental or guardian consent should be legally inadequate.

204. Assuming that surgical castration is effective for modifying compulsive sexual behaviour.

205. Criminal Code, 8. 45. 
withdrawing his consent. Obviously, an unconscious person who has not given prior consent should never be a donor. Of course, when there is an active misrepresentation on the part of the surgeon, the consent given is invalid.

It could be argued that a live donor should not be able to consent to a serious operation upon himself for the benefit of another, especially when as a result of the removal of the donated organ, his health may be seriously endangered with only the prospect of a moderate prolongation of the receiver's life. Some day the donor could be in need of the missing organ.

The Quebec Civil Code allows a person of full age to consent in writing to the disposal inter vivos of a part of his body provided that the assumed risk is not disproportionate to the benefit anticipated. The alienation must be gratuitous unless its object is a part of the body susceptible of regeneration. ${ }^{206}$ The various Human Tissue Gift Acts in force in the common law provinces also provide that: ${ }^{207}$

Any person who has attained the age of majority, is mentally competent to consent, and is able to make a free and informed decision may in a writing signed by him consent to the removal forthwith from his body of the tissue specified in the consent and its implantation in the body of another living person.

Stricter standards should be applied to the donor's consent than to the recipient's consent. For instance, in the case of a live donor, it may be advisable to assess his physical and psychiatric health as a condition precedent to his giving an organ. This examination could be made by a board consisting of an independent physician, the surgeon who will carry out the transplantation operation and a representative of the hospital where the operation will be performed or of the Department of Health. Another solution would be to require the donor's consent to be given to a judge or magistrate of his domicile, or residence or of the district in which the transplantation will take place. The judge or magistrate or the medical board would make sure that the volunteer donor is free from undue influence. This is particularly important in the case of prisoners. Actually, it is better to refuse transplants from persons under restraint, although it may be inequitable to prevent them from making a sacrifice for a loved one in desperate need. Where there is evidence that strong pressures are exercised on the donor, he skould not be allowed to give consent. Finally, it is essential that the consent of the donor be revocable at any time. The legislation presently in force in Canada does not contain such elaborate methods for insuring free consent.

In the case of minors, when the operation is for the benefit of another, the consent of both the parent or guardian and minor should not be dispensed with under any circumstances. Actually, from a public policy point of view, it is advisable to prohibit any operation that is not beneficial to the child. Another approach would be to obtain the court's authorization. For instance, the court's authorization was obtained for the first time in Massachusetts in 1957 when several requests were made for the transplantation of a kidney in identical twins who were under 21 years of age. In order to be fully protected against possible criminal and civil liability, the hospital trustees and surgical staff of the Peter Bent

206. Art. 20. In France see Projet de réforme du Code civil: Droits de la personnalite, art. 4, alinea 1: “L'acte par lequel une personne dispcse de tout ou partie de son corps est interdit lorsqu'il doit recevoir effet avant le décês du disposant, s'il a pour effet de porter une atteinte grave et definitive a l'integrité du corps humain."

207. E.g., Ontario Act, supra, n. 13, 8. 3(1). 
Brigham Hospital in Boston sought a declaratory judgment as to whether they should be allowed to perform such a transplantation. In Masden v. Harrison ${ }^{208}$ and in two other cases, ${ }^{209}$ the court authorized the hospital and surgeons to proceed with the operations. ${ }^{210}$

In each of the three cases, the court relied upon the testimony of the parents, the fact that the donor and recipient had given their consent after being fully informed of the nature of the operation and its possible consequences, and psychiatric evidence indicated that grave emotional disturbance could affect the health and physical well-being of the donor if the operation could not take place, and that the recipient would die as a result of the refusal. Thus, the operation was deemed to be for the benefit of the donor as well as of the recipient. Actually the benefit was more the prevention of a possible detriment to the donor. These operations involved twins, and it is questionable whether this argument could be invoked when the donor and the recipient are not related.

It must be noted that in these cases the court pointed out to the hospital and the surgeon the importance of obtaining not only the consent of the parents but also the consent of each of the twins after they had been fully informed of the nature of the operation and its possible consequences, and it was clear that each understood the situation. The minors involved were at least fourteen years old. Would their consent have been required if they had been younger or incapable of understanding the operation and its consequences?

Assuming that medically it is feasible and advisable to transplant organs from small children, it would seem wrong for a court to allow the operation on the donor, even if parental consent has been obtained. The courts or the parents should not be allowed to deprive a child of one of his vital organs without his consent or his intelligent comprehension. ${ }^{211}$ Whether a minor donor close to maturity should be able to give his consent if he is intelligent enough to understand the nature and consequences of his act is a difficult question to answer. As in the case of adult donors some control is needed to make sure that the minor's consent is the result of his own decision free from pressure and coercion. In the case of a recipient minor the situation is different.

Although it is difficult to determine the precise age under which a child should have no capacity to assent to an operation, it would seem that a child less than sixteen years old is too young to give a valid consent under some circumstances. Public policy demands legal protection of the personal rights as well as the property rights ${ }^{212}$ of individuals who are incapable of intelligent decision by reason of their youth.

208. No. 68651 Eq. Mass. Sup. Jud. Ct., June 12, 1957.

209. Huskey v. Harrison, No. 68666 Eq. Mass. Sup. Jud. Ct., August 30, 1957; Foster v. Harrison, No. 68674 Eq. Mass. Sup. Jud. Ct., Nov. 20, 1957. See also Hart v. Brown (1972), 289 A. 2d 386, 29 Conn. Supp. 368, noted, Allensworth (1972), 4 Texas Tech. L. Rev. 244.

210. For an analysis of the cases, see Curran, A Problem of Consent: Kidney Transplantation in Minors (1959), 34 N.Y.U.L. Rev. 891.

211. In Bonner v. Moran (1941), 126 F. $2 d 121$ (D.C.), a case involving a 15-year-old donor, the Court of Appeals was of the opinion that the Trial Judge had erred in charging that if the jury believed that the boy himself was capable of appreciating and did appreciate the nature and consequences of the operation and actually consented or by his conduct impliedly consented, the verdict must be for the surgeon. The court rejected $\mathrm{B}$. 59 (1) of the American Law Institute, Restatement of the Law of Torts, which takes the view that if the minor is capable of appreciating the consequences of the invasion and gives an informed consent, there is no liability even though the parent or guardian has not consented. See also 8. 892. In England, a child 16 years of age may validly consent to an operation: Family Law Reform Act, supra, n. 159, s. 8(1).

212. In the case of a donor of a transplant who is a minor, the issue does not appear to be one of property law. Thus it is not necessary to obtain the judicial approval which is often required when dealing with property rights of a minor. 
When the donor of a transplant is of unsound mind, authorization for the operation should be obtained from the person in whose custody or care the patient has been committed. Morally or ethically it would be wrong to allow a mentally deficient person to be a donor. ${ }^{213}$

In the common law provinces that have a Human Tissue Act in force, persons who have not attained the age of majority or are mentally incompetent persons who are unable to make a free and informed decision cannot give a valid consent for the purposes of the Act. However, if any of these persons gives his consent, it is valid if the person who acted upon it had no reason to believe that the person who gave it had not attained the age of majority, was not mentally competent to consent, and was not able to make a free and informed decision, as the case may be. This is a dangerous provision although it is intended to protect the operating physician. What is clear from the Act is that parents may no longer dispose of their minor children's organs or tissue. Control of minors donating for other than transplantation is governed by general law which means that parents cannot permit harm to be done to their children.

Since a person under the age of majority, which in Ontario is eighteen, cannot make a valid inter vivos gift of tissue ${ }^{214}$ for transplants, this may cause some difficulties in the case of identical twins who have not attained the age of majority. Shall one let the other die?

In the Province of Quebec, the Civil Code provides that a minor capable of discernment, if he is authorized by the person who exercises paternal authority, and by a judge of the Superior Court may dispose inter vivos by gratuitous title, of a part of his body provided that no serious risk to his health results therefrom. His consent must be in writing and may be revoked. This article is quite liberal.215

\section{Non-Therapeutic Clinical Research in which Experiments \\ Are Not Expected to Benefit the Subject But Are Designed \\ to Add to the Understanding of Normal and Diseased States}

In the case of non-therapeutic clinical research in which experiments are not expected to benefit the subject, it could be argued that consent should be null and void as against public policy. After all, a physician's sole duty toward his patient is to attempt to achieve a cure. Yet, it must be recognized that experiments are necessary to add to the understanding of normal and diseased states in order to develop new treatments or drugs. Thus, it would be most unwise to forbid all types of experiment. When the subject is healthy and the experiment is not likely to cause him any substantial harm or in any way to endanger his life, the experiment is not against public policy provided it is useful to society. If the experiment is not a serious one consent to it is not effective. For instance, if the risk is greater to the subject than the benefit to be derived by society, the experiment is not a serious one and must be declared illicit.

The consent to a licit experiment must be free and informed. The usual

213. Lausier v. Pescinski (1975), 67 Wis. 2d 4, 226 N.W. 2d 180; but see Strunk v. Strunk (1969), 445 S.W. 2d 145 (Ky.); and Robertson, Organ Donations by Incompetents and the Substituted Judgment Doctrine (1976), 76 Col. L. Rev. 48.

214. "Tissue" includes an organ but does not include any skin, bone, blood, blood constituent or other tissue that is replaceable by natural processes of repair. This means that minors may be capable of giving, what is not included in the definition of tissue, provided the rules applicable to them are followed: e.g., consent of the minor himself if close to maturity or that of the parent or guardian who has control of the minor. In general see Sharpe, supra, n. 157.

215. See Mayrand, supra, n. 23 at 67 et seq. 
principles of consent apply to experimental medical procedures. However, because the risk may be more important and there is no benefit to the subject, he must be informed to a much greater degree than a patient in the case of therapeutic treatment.

In Canada, in Halushka v. University of Saskatchewan, ${ }^{216}$ the Saskatchewan Court of Appeal held that:217

... the duty imposed upon those engaged in medical research . . . to those who offer themselves as subject for experimentation . . . is at least as great as, if not greater than, the duty owed by the ordinary physician or surgeon to his patient. There can be no exceptions to the ordinary requirements of disclosure in the case of research as there may well be in ordinary medical practice. The researcher does not have to balance the probable effect of lack of treatment against the risk involved in the treatment itself. The example of risks being properly hidden from a patient when it is important that he should not worry can have no application in the field of research. The subject of medical experimentation is entitled to a full and frank disclosure of all the facts, probabilities and opinions which a reasonable man might be expected to consider before giving his consent.

This passage represents the approach to be followed in the common law provinces in the absence of statutory provisions dealing with experimentation on human subjects.

In Quebec, article 20 of the Civil Code allows a person of full age to submit to an experiment provided that the risk assumed is not disproportionate to the benefit anticipated. "Experiment" seems to refer to scientific or non-therapeutic experiments. Although, it is not clear whether the benefit anticipated must accrue to the healthy subject or to others, the word benefit must be taken to mean future benefit to persons other than the one submitting to the experiment. ${ }^{218}$ The Quebec Civil Code does not deal with the requirements of informed consent to an experiment. However, there is no reason to believe that Quebec courts would reject the views expressed by the Saskatchewan Court of Appeal in the Halushka case.

The difficulties involved in securing an informed consent in the case of experiments must not be underestimated. To give one example, often no one knows what the risks or benefits will be. Thus, under some circumstances, informed consent alone may not adequately safeguard the rights of the subject. This is why in the United States of America, in some cases, additional rules and procedures have been devised for the control of human experimentation. ${ }^{219}$ Should reckless experimentation result in the death of the subject or his injury, sections 208,228 or 244 of the Criminal Code would be applicable and the physician could not rely on section 45 or on the common law defence of necessity.220

Since 1945, there have been many attempts to lay down guidelines concerning the requirement of free and informed consent to medical experiments.

For instance, the Nuremberg Code states in part:221

216. Supra, n. 27. See also Cryderman v. Ringrose, supra, n. 27.

217. Per Hall J.A. at 443-444. In the U.S.A. see Hyman v. Jewish Chronic Disease Hospital, supra, n. 27.

218. Bowker, Experimentation on Humans and Gift of Tissue: Articles 20-23 of the Civil Code (1973), 19 MoGill L.J. 161 , at 166 and Mayrand, supra, n. 23 at 42.

219. A detailed study of these rules is outside the scope of this research. See for instance Ratnoff, Who Shall Decide When Doctors Disagree, etc. (1974-75), 25 Case Western Reserve L. Rev. 472; Cowan, Human Experimentation: The Review Process in Practice (1974-75), 25 Case Western Reserve L. Rev. 533.

220. Note that the physician may also be liable in tort or in contract. In general see Dickens, Information for Consent in Human Experimentation (1974), 24 U.T.L.J. 381; Waddams, Medical Experiments on Human Subjects (1967), 25 U.T. Fac. of L. Rev. 25.

221. United States v. Brandt, 2 Trials of War Criminals Before the Nuremberg Military Tribunals (The Medical Case) 182-82 (Military Tribunal I, 1947). 
1. The voluntary consent of the human subject is absolutely essential.

This means that the person involved should have legal capacity to give consent; should be 80 situated as to be able to exercise free power of choice, without the intervention of any element of force, fraud, deceit, duress, over-reaching, or other ulterior form of constraint or coercion; and should have sufficient knowledge and comprehension of the elements of the subject matter involved as to enable him to make an understanding and enlightened decision. This latter element requires that before the acceptance of an affirmative decision by the experimental subject there should be made known to him the nature, duration, and purpose of the experiment; the method and means by which it is to be conducted; all inconveniences and hazards reasonably to be expected; and the effects upon his health or person which may possibly come from his participation in the experiment.

The duty and responsibility for ascertaining the quality of the consent rests upon each individual who initiates, directs, or engages in the experiment. It is a personal duty and responsibility which may not be delegated to another with impunity.

9. During the course of the experiment the human subject should be at liberty to bring the experiment to an end if he has reached the physical or mental state where continuation of the experiment seems to him to be impossible.

The Declaration of Helsinki adopted by the eighteenth World Medical Assembly in 1964 and revised in Tokyo in 1975, contains recommendations for the guidance of physicians doing biomedical research that involves human subjects.

Some of the basic principles are as follows:222

9. In any research on human beings, each potential subject must be adequately informed of the aims, methods, anticipated benefits and potential hazards of the study and the discomfort it may entail. He or she should be informed that he or she is at liberty to abstain from participation in the study and that he or she is free to withdraw his or her consent to participation at any time. The doctor should then obtain the subject's freely-given informed consent, preferably in writing.

10. When obtaining informed consent for the research project the doctor should be particularly cautious if the subject is in a dependent relationship to him or her or may consent under duress. In that case the informed consent should be obtained by a doctor who is not engaged in the investigation and who is completely independent of this official relationship.

The ethical principles of various medical associations contain similar rules. For instance, the Code of Ethics approved by the General Council of the Canadian Medical Association in June 1975 states:

Before proceeding he [the clinical researcher] will obtain the consent of those individuals or their agents, and will do so only after explaining the purpose of the clinical research and any possible health hazard which he can foresee.

The Report of the Consultative Group on Ethics to the Canada Council published in 1976 contains some very important ethical principles with respect to informed consent. These principles are quoted in full because they are the most comprehensive ones on this topic:

The single most important device for resolving the dilemma between the need to respect the rights of the people participating in research and the need to provide for the advancement of knowledge is the procedure of informed consent-informing the potential participants of the nature of the research, the risks and benefits, and allowing them to decide for themselves whether or not they wish to participate.

It is axiomatic that no research involving humans should be undertaken without their freely-given, informed consent, if possible in writing, and that investigators should honor all commitments associated with such agreements. The information given to a subject should be complete and presented in a way which takes into consideration the level of his comprehension. An exact description should be provided of all aspects of the research project, its purpose, usefulness, expected benefits, methods, foreseeable effects, risks (including possible hazards to physical and psychological well-being and jeopardy

222. See also III, Non-Therapeutic Biomedical Research Involving Human Subjects. 
of social position) and where appropriate, a description of alternative procedures which might be used. It should be possible to assure subjects that the research in the form to which they are giving consent will be closely monitored. Subjects should always be apprised of any considerations which might lead them to refuse to participate. At the same time, an offer should be made to answer inquiries concerning the research. While the researcher will be the primary person responsible for answering such inquiries, he should whenever practicable be willing to suggest a second, knowledgeable person, other than a member of the research group, if the subject wishes further information and review concerning the proposed subject.

Since research by its very nature involves the unknown, the subject should understand that it is unrealistic to expect identification of all possible risks; nonetheless, he should be reassured that any research procedure which involves risk to the participant has been carefully pretested.

While it is desirable that subjects be informed of the uses to which any of the data collected will be put, we recognize that in the case of questionnaires deposited in a data bank often no single purpose can be specified, as they may later be used in the analysis of problems unrelated to the original reasons for the data collection. The precautions initially taken to ensure anonymity of responses may make it impossible to locate the participants a second time to obtain their informed consent to a new analysis of the data. This should be explained to participants and a general consent obtained to re-use data with a guarantee of anonymity.

Informed consent must be freely and explicitly given, without any form of coercion, constraint or undue inducement. It is accepted that subjects may be remunerated for the time they give to participating in a project, and that this remuneration may take into consideration the trouble or inconvenience which their participation involves. However, other more subtle forms of inducement, such as higher marks or favourable publicity, are not permissible. And remuneration ought never to be such as to lead a subject to ignore the risks involved in participation. Moreover, potential subjects should always be advised that they may withdraw from the project at any time.

It may not always be possible to obtain written consent, but in cases where this is not done, the researcher should be required to describe the procedures used to obtain consent and to give satisfactory reasons for not obtaining written consent.

The consent form itself is the tangible evidence of an act of voluntary co-operation between the researcher and his subject, based on the subject's understanding of what is implied in the consent. It is, in effect, a contract, and its purpose is the protection of both the subject and the researcher and no less the sponsoring institution and community as a whole.

The form of consent should set out:

(1) the purpose of the research;

(2) the benefits envisaged;

(3) any inconveniences involved;

(4) the tasks to be performed;

(5) the rights of the subject, i.e., the right to withdraw at any time without penalty, the right to confidentiality of personal information;

(6) any departures from normal practice being planned by the researcher;

(7) the risks involved;

(8) the name of the person, group or institution eliciting or receiving the consent.

The wording of the consent form should be as similar as possible to the verbal description given to the subject. The form should provide for hearing any complaint the subject may subsequently have.

We would emphasize that those participating in a research project should never, either before or after the experiment, have any reason for saying that they did not fully understand what was involved. Moreover, while consent alone is never sufficient to justify research involving humans, it is a prerequisite to carrying it out.

It is understood that in working in the field outside one's own culture, fully informed consent may be impossible to obtain. In such circumstances, extra care should be taken by the researcher to protect the interests of participants and third parties in the research. Moreover, in field research consent should always be obtained from the appropriate authorities for the use and relocation of objects belonging to the community under study.

We urge the adoption of the following guidelines on informed consent:

(1) that with due concern for the limitations of their comprehension, potential 
participants be given a full and fair explanation of the purpose of the research and the procedures to be followed, together with a careful estimate of the risks and benefits;

(2) that no coercion or other form of undue financial or other inducement be used to obtain subject participation;

(3) that it be made clear to participants that they may withdraw their participation at any time, just as the investigator may conclude his research at his own discretion in the interest of the subjects, the project or himself;

(4) that, where practical, informed consent of both parents and children always be obtained in respect of research involving children;

(5) that special precautions be taken to protect captive populations from being coerced into participation;

(6) that participants be explicitly assured of confidentiality;

(7) that participants be apprised of their rights to inquire about the research, and that whenever practicable they have recourse of a knowledgeable resource person outside the research group for that purpose;

(8) that informed consent always be obtained in writing and where this is not possible, that the procedures to be used in obtaining consent be clearly described and open to examination.

There is no need to add other examples of ethical principles or guidelines as they all contain similar provisions. ${ }^{223}$ As noted previously, ${ }^{224}$ in the United States, the Department of Health, Education and Welfare has codified ${ }^{225}$ existing policies for the protection of human subjects with respect to experiments supported by grants from that Department. 226

\section{(a) Minors}

The problem of informed consent to non-therapeutic clinical research eludes solution with respect to those who suffer from some legal disability.

Should minors be allowed to participate in non-benefit experiments when they are unable to consent or to comprehend procedures which they may undergo, or more generally when they are not capable of discernment? Should the parents' consent alone be sufficient, or should a court participate and be the final arbiter in the decision?

The Helsinki declaration as amended in Tokyo merely states that:

11. In case of legal incompetence, informed consent should be obtained from the legal guardian in accordance with national legislation. Where physical or mental incapacity makes it impossible to obtain informed consent, or when the subject is a minor, permission from the responsible relative replaces that of the subject in accordance with national legislation.

The principle is not very helpful.

In the United States, Bonner v. Moran ${ }^{227}$ by implication approves a minor's participation in a non-therapeutic procedure provided the consent of the parent has been obtained. Yet this may be questionable when the procedure is not for the direct benefit of the minor. On the other hand, a mature minor should be able to validly consent to a scientific experiment.

223. See e.8., Medical Research Council of Canada, Ethics in Human Experimentation 12, 16-34 (1978). Academie Suisse des Sciences Medicales, Directives pour la recherche experimentale sur l'homme, arts. II 8, III and IV, (1970). American Psychological Association, Ethical Principles in the Conduct of Research with Human Subjects (1972). Levine, Guidelines for Negotiating Informed Consent with Prospective Human Subjects of Experimentation, 22 Clinical Research 42, (1974). Hershey, Miller, Human Experimentation and the Law (1976).

224. Supra, p. 346.

225. 45 C.F.R. \$ 46. 1-22 (1974). See also National Research Service Award Act 1974, Publ. L. No. 93-348, tit. II, 88 Stat. 342, 8. 202(a)(I)(B)(C), 42 U.S.C. \$ 289 1-1. In experiments involving the use of investigational new drugs, the manner of procuring consent must conform to Food and Drug Administration Policy, 21 C.F.R. $\$ 3310$. 102(h), 316.1 (April 1, 1977).

226. See Ratnoff, supra, n. 219 at 511-512.

227. Supra, n. 211. 
In Quebec, article 20 of the Civil Code allows a minor capable of discernment to submit to an experiment with the consent of the person having the paternal authority and of a judge of the Superior Court, provided that no serious risk to his health results therefrom. This provision would seem to supersede the principle that a tutor must take care of his pupil and can only consent to acts for the benefit of his pupil. ${ }^{228}$ However, article 20 is restricted to minors capable of discernment. Experiments on minors below the age of discernment appear to be forbidden.

In the common law provinces, there is no statutory provision dealing with the question, but it may be assumed that parents and guardians of minors can give consent on their behalf to any procedures even if they are of no particular benefit to such minors provided they do not carry some risk of harm. ${ }^{229}$ Minors who are capable of appreciating fully the nature and consequences of a particular experiment appear to be in the same position as adults with respect to consent.230

Since a strict no-experiment rule would not be realistic, the United States Department of Health, Education, and Welfare has proposed policies and procedures designed to give special protection to children and mentally defective persons when they are involved in research, development and demonstration activities funded by federal grants:

1. Children. If the health of children is to be improved, research activities involving their participation is often essential. Limitation of their capacity to give informed consent, however, requires that certain protections be provided to assure that scientific importance is weighed against other social valyes in determining acceptable risk to children. Therefore, research, development, and demonstration activities which involve risk to children who participate must:

a. Include a mechanism for obtaining the consent of children who are 7 years of age or older;

b. Include the applicant's proposal for use of a Protection Committee which is appropriate to the nature of the activity;

c. Be reviewed and approved, in conformity with present DHEW policy, by an Organizational Review Committee; and

d. Be reviewed by the appropriate agency Primary Review Committee, the Ethical Review Board, and the appropriate Secondary Review Group.

4. The mentally infirm. Insofar as the institutionalized mentally infirm might lack either the competency or the autonomy (or both) to give informed consent, their participation in research requires additional protection:

a. Research, development and demonstration activities involving the mentally infirm will be limited to investigations concerning (1) diagnosis, etiology, prevention, or treatment of the disability from which they suffer, or (2) aspects of institutional life, per $s e$, or (3) information which can be obtained only from such subjects.

All research, development and demonstration activities involving such persons must:

1. Include the applicant's assurance that the study can be accomplished only with the participation of the mentally infirm;

2. Include the applicant's proposal for use of a Protection Committee which is appropriate to the activity; and

3. Be reviewed and approved by an Organizational Review Committee, in conformity with present DHEW policy. ${ }^{231}$

\section{Furthermore:}

228. Art. 290 Civil Code.

229. However, minors cannot be donors of tissue: see supra, n. 214. Compare Medical Research Council of Canada, supra, n. 223 at $30-31$.

230. In general see McCormick, Proxy Consent in the Experimentation Situation (1974), 2 Perspectives in Biology and Medicine 20, Capron, Legal Considerations Affecting Clinical Pharmacological Sludies in Children (1972), 21 Clin. Res. 141.

231. See e.g., Federal Register, Vol. 38, No. 221, Nov. 16, 1973, pp. 31738-31739. 
D. Special provisions-1. Consent of both parents. Even where State law may permit one parent alone to consent to medical care, both parents have an interest in the child, and therefore, consent of both parents should be obtained before any child may participate in research activities. Since the risks of research entail the possibility of additional burdens of care and support, the consent of both parents to the assumption of those risks should be obtained except when the identity or whereabouts of either cannot be ascertained or either has been judged mentally incompetent. If the consent of either parent is not obtained, written explanation or justification should be provided to the Protection Committee. Consent of school or institutional authorities is no substitute for parental concern and consent.

2. The child's consent. An important addition to the requirement for parental consent is the consent of the child subject. Clearly infants have neither the comprehension nor the independence of judgment essential to consent; older children might or might not have these capabilities. Although children might not have the capacity to consent on their own to participate in research activities, they must be given the opportunity (so far as they are able) to refuse to participate. The traditional requirement of parental consent for medical procedures is intended to be protective rather than coercive. Thus, while it was held to be unlawful to proceed merely with the consent of the child, but without consent of the parent or legal guardian, the reverse should also hold. Therefore, in addition to consent of both parents, consent of the child subject must also be obtained when the child has attained the common law "age of discretion" of 7 years, unless the agency Ethical Review Board specifically exempts a project from this requirement.

3. Exclusions. Despite all the protections afforded by these procedures, certain children are categorically excluded from participation in research involving risk. These include children with no natural or adoptive parents available to participate in consent deliberations and children detained by court order in a residential facility, whether or not natural or adoptive parents are available.

Although these regulations appear to be sensible, it is suggested that no one should have the right or authority to subject minors or mentally incompetent persons to the potential risks of an experiment as parents or guardians have a duty to act in the interest and for the benefit of the minor or mentally incompetent person committed to their care.

In Canada the Report of the Consultative Group on Ethics to the Canada Council (1976) states that:

In view of the possibility of long-range harm, because of their age, developmental and psychological processes and the problems associated with gaining their informed consent, we are especially concerned about ethical practices in research on children. Ideally, we should like to have advocated that only research producing results which would be directly beneficial to the children involved should be carried out. But the fact is that, despite the possible overall benefits, most research has minimal, if any, immediate or direct benefit to those involved in the study. This situation imposes a very heavy burden of responsibility in the case of research on children, particularly where behavioural manipulation is involved. Accordingly, we feel that the following safety measures are in order in addition to those stated elsewhere in this report. The informed consent of parents should always be obtained for research with minors. In the rare cases where the precise purpose of the research cannot be divulged to the parents in case they might try to influence the child's performance, they should always be told of the procedures to which their child will be subjected. Despite the informed consent of parents, we believe that any individual child should be able to refuse to participate in the research study or to withdraw his participation at his own request.

As an extra precaution, institutional review committees should not hesitate to seek expert advice on the potential short or long-term risks in a proposed research project with children if they themselves do not feel competent to make such judgments. Moreover, we believe that once the research is under way, early monitoring procedures are important, especially in educational research where experiments are being carried out with children in learning environments.

We urge the adoption of the following guidelines in respect of research on children:

(1) that the informed consent of parents always be obtained before experimenting with minors;

(2) that, in the rare cases where the precise purpose of the research cannot be divulged to the parents, they always be told of the procedures to which their child will be subjected; 
(3) that each individual child will be given the opportunity to refuse to participate in the research or withdraw his participation at his own request;

(4) that review committees seek expert advice, whenever necessary, on potential short-

or long-term risks to children;

(5) that early monitoring procedures be employed to uncover any unforeseen risks in research involving children.

The Working Group on Human Experimentation in its report to the Medical Research Council on Ethical Considerations in Research Involving Human Subjects proposes that consent on behalf of those unable to consent for themselves should often involve two stages:

In the first, the parent or legal guardian of the child or the mentally incompetent person is asked to consent on behalf of the potential subject, ... If consent is refused at this level, then that potential subject may not, under any circumstances, be submitted to the research. Only if consent at this first level is given can the second level of consent be contemplated.

The second level of proxy consent is to be given by a subject advocate or ombudsman. This person should be attached to, and be an integral part of, the hospital or institution in which the research is to be performed.

The intent of the second level of proxy consent is to allow recognition of factors of which the first level of proxy consent may not be aware. It therefore applies primarily to potential research subjects who are hospitalized or in mental institutions, and with whom the first proxy may be in only occasional contact.

The above applies to all who are totally incapable of giving an informed consent, namely young children and those suffering severe mental incapacity. Between these groups and those with full capacity for consent there are potential subjects who, despite mental illness or the lack of maturity, are capable to varying degrees of understanding a research protocol and therefore of consenting on their own behalf. Where such subjects are involved, the ethics review committee should evaluate risks and benefits in terms of the capacity of the proposed subjects before determining the extent to which the subjects should be involved in the consent process and whether one or two levels of proxy consent are needed. ${ }^{232}$

\section{(b) Prisoners}

Prisoners have been used in medical experimentation since man conceived prisons. Yet is it possible to consider their consent voluntary especially when they hope that their participation in research will be viewed favourably by prison authorities and by the parole board? While there is no legal or moral objection to the participation of normal volunteers in research, there are problems surrounding the participation of volunteers who are confined in an institution. It would seem that the special status of prisoners requires that they be given special protection when they participate in research.

Statutes and regulations around the world which deal with experimentation with and research on prisoners range from permission to total bans of such research. Where any sort of research involving prisoners is permitted, a requirement that informed consent be obtained is explicitly set forth. Where financial or other rewards are explicitly covered, they are generally limited or prohibited.

It is obvious that where liberty is limited, and where freedom of choice is restricted, there is a corresponding limitation on the capacity to give a truly voluntary consent. Although the prisoner might be adequately informed, and competent to make judgments, the voluntariness of his consent remains open to question. For these reasons, in Canada, the use of prisoners is strongly disapproved if not actually prohibited. 
In the United States of America the Department of Health, Education, and Welfare has recommended certain policies and procedures to protect prisoners participating in a research project which it has funded. Prisoners can consent to be subjects if adequate safeguards are provided. Research, development, and demonstration activities involving prisoners must:

a. Include the applicant's proposal for use of a Protection Committee, which is appropriate to the nature of the activity;

b. Be reviewed and approved by an Organizational Review Committee which may already exist in compliance with present DHEW policy or which must be appointed in a manner approved by the appropriate DHEW agency:

c. Be reviewed by the agency Primary Review Committee; and

d. Be conducted in an institution which is accredited by the Secretary of Health, Education and Welfare.

The safeguards include: ${ }^{233}$

a required certification by a review committee that there are no undue inducements to participation by prisoners, taking into account the comparability of the earnings otherwise offered; a requirement that no reduction in sentence or parole in return for participation in research be offered unless it is comparable to what is offered in return for other activities; and a provision for accreditation by DHEW of prisons in which research is to be supported or conducted. A subsequent DHEW Notice of Proposed Rule making dated August 23, 1974 adds a requirement that the review committee also take into account whether living conditions, medical care, and so on would be better for participants than those generally available to prisoners, but deletes the provision for accreditation by DHEW.

The report by the Centre for Law and Health Sciences of the Boston University School of Law also recommends that provision for accreditation by the Department of Health, Education and Welfare should be made, to ensure that research will not be conducted:

under such circumstances that participation is the only way for a prisoner to obtain minimally decent living conditions; that the rewards for participation should not be such that they provide the only way for a prisoner to maintain his health and personal hygiene, or induce a person to incur great personal risks; that parole or a reduction in sentence should never be offered in return for participation in research; that there should be some provision for the protective role of an independent counselor; that full information about the research should be given the prospective participant, and that he should not be asked to waive his rights against anyone for injuries that he might sustain.

These safeguards would enable a prisoner to give a valid informed consent to research.

In Canada the Report of the Consultative Group on Ethics to the Canada Council also deals with research on captive populations:

Another area we believe to be of great sensitivity is research on captive populations, which we define as individuals or groups who are in a relationship with others involving a power differential which could operate to their disadvantage as subjects. Thus minors, prisoners, students, employees, minority groups, incapacitated people and the socially deprived might well be involved.

The problem here is one of ensuring that consent is not in some way or to some degree the result of coercion. We do not consider the consent of a person in authority to constitute informed consent of subjects in subordinate positions. Consent of the subjects themselves should always be obtained. To ensure that consent is not gained through subtle pressures being brought to bear on captive subjects, it would seem prudent for institutional committees reviewing projects to seek advice from someone with special expertise as to the forces likely to be operating on the captive group, such as how records

233. See e.g., Federal Register, Vol. 42, No. 10, Jan. 14, 1977, at 3076; see also Herch, Flower, Medical and Psychological Experimentation on California Prisoners (1974), 7 U. of Cal. Davis 351; Todd, No-Therapeutic Prison Research: An Analysis of Potential Legal Remedies (1975), 39 Albany L. Rev. 799. 
are kept on them and how they are rewarded or penalized. There should, for instance, be no interference with prisoners which involves any risk or disrespect or encroaches upon the individual's fundamental rights. For if a prisoner sees his co-operation in an experiment as a means of improving his lot, the direct or indirect pressure implied in this situation invalidates the consent.

Where consent of the subjects themselves cannot be obtained, consent must be sought from someone in authority, together with written consent from an impartial person who may act as an independent advocate. As a further protection, we recommend that captive populations always have the power of veto over their participation in a research
project.

We receommend with respect to captive populations: (1) that, in addition to consent of the authorities, the consent of the subjects themselves
be obtained;

(2) that, where it is not possible to obtain the informed consent of the subjects, the written consent of an impartial person be obtained, in addition to the consent of the authorities;

(3) that captive subjects always have the right and power to veto consent given by the authorities or an impartial person for their participation in the research; (4) that special care be taken with respect to all other ethical principles where captive
populations are involved.

What emerges from a comparative study of the ethical and legal rules applicable to non-therapeutic clinical reasearch in which experiments are not expected to benefit the subject is the requirement of informed consent freely given by the subject or his proxy or both plus a review of the project by an independent review committee. This is a good approach to the problem, although the non-professional members of such committee may have difficulty deciding whether the risk to the subject is minimal.

\section{CONCLUSIONS}

Recent medical advances make it imperative to determine (a) the cases in which consent should be legally effective and (b) what is meant by legally effective consent.

In the medical field, consent takes on a special importance. Most, if not all of us, have a vested interest in this issue, since so many people undergo some form of surgical operation or at least some medical treatment during the course of their lives. It would be frightening to think that our bodies could be tampered with without our consent, and that such an action would be lawful. As Peter Strauss writes:234

Even in our socialistic age the law of most Western democracies has retained its individualistic spirit to such an extent that the decision whether he wants to be cured or not is left to the patient. Therefore justification for the medical operation is still fundamentally to be found in his consent. This, it is submitted, is the proper view.

However, this does not mean that every operation performed without the patient's consent should be illicit. It is preferable to say that if an operation is performed against a patient's will, it is illicit. If an operation is performed merely without the patient's consent, it may still be legally justifiable. This would be the case in an emergency situation when the patient is unconscious. The "individualistic spirit" mentioned by Strauss is still preserved, in that it is sacrificed only when the public interest is affected, for it is certainly in the public interest to preserve the high value placed on human life. Similarly, it would be against the interests of our liberal society to uphold operations performed specifically against the patient's will. 
It is recommended that the criminal law and the civil law should interfere as little as possible with the daily work of the medical profession in order to encourage medical advances for the benefit of society in general and the patient in particular..$^{135} \mathrm{~A}$ balanced formula must be found which protects both the physician and his patient. The doctrine of informed consent expressly and freely given seems to achieve this balance provided its constituent elements are well defined and consent is viewed as the expression of a responsible choice by the patient or subject, and an ongoing process.

Assuming that there is a duty to inform, the criteria for informed consent freely given must take into consideration (1) the status of the person giving his or her consent (for instance, whether he is a patient, a subject, an adult, a minor, or a prisoner) in order to insure that he or she is a responsible patient or subject and that the choice which the consent expresses is freely made, and (2) the nature of the contemplated procedure (for instance, whether therapeutic or non-therapeutic or experimental) as the type of information to be given the patient or subject depends upon it. Thus, it would seem to be advisable to indicate the form consent should take (for instance, in writing in the presence of two witnesses in order to avoid any error as to the existence of consent on the part of the physician or researcher) and the persons who can give a valid informed consent (for instance, persons who are capable or discernment).

Informed consent is sufficient to protect an individual's health and bodily integrity as well as his dignity. However, in ascertaining whether the patient understands the proposed treatment or experiment and assents voluntarily to its performance, it is the conduct of the physician that must be judged rather than that of the patient or subject. If the physician adjusts to the rules of informed consent he should not fear any criminal or civil liability.

It is suggested that no differences should exist as to the effects of informed consent between the private law and the criminal law. However, the criminal law could determine the upper limits of the efficacy of consent as an expression of public policy which would then be applicable to the private law. This may be difficult to achieve in a federal state like Canada because of the division of legislative powers.

As already noted, when consent is effective it removes the illicit character of the act. Consent should have nothing to do with intent or mens rea as it affects the objective not the subjective element of an offence. Whether consent should be made a valid justification for a particular act involves serious policy considerations. The protection of public order and the fostering of individual freedom at times may conflict. When the acts contemplated infringe private rights and interests only and not those of the State or of society, consent should be a valid justification recognized by the Criminal Code.

With respect to the right to life, it is suggested that article 14 of the Criminal Code be modified to take into consideration the motive for consenting to death. When the reasons for an offence are noble, a lesser penalty should be imposed or the elements or nature of the offence should be changed. Thus, in the case of voluntary euthanasia the penalty should not be as severe as in the case of culpable homicide, although it may be advisable to distinguish between the situation where death is ad-

235. See McLean v. Weir, supra, n. 27 at 627 per Gould J: "The less the courts try to tell doctors how to practice medicine the better." 
ministered at the request of the patient and the situation where it is administered with his consent. This does not mean that voluntary or involuntary euthanasia should be legalized. It is a matter of public policy outside the scope of this article. On the other hand, it is submitted that the California Natural Death Act could be worked into the Criminal Code so as not to conflict with sections 14 and 212.

Also, a special section could be included in part I of the Criminal Code dealing with consent as a cause of justification. For instance article 50 of the Italian Penal Code provides that:

\footnotetext{
A person who damages the property or infringes a right with the consent of the person or persons who may legally dispose of it does not commit an offence.

A person can only dispose of property or a right if its infringement is not directly contrary to public order or public interest.

No valid consent can be given by a non emancipated minor under the age of 21 or with respect to his extra patrimonial rights, by an emancipated minor or an insane person.

Consent given by error, or as a result of violence, threats or fraud is not valid.
}

With respect to the right to physical and mental integrity, it is suggested that there is no need for special legislation. The doctrine of informed consent freely given seems to be adequate. However, with respect to non-therapeutic clinical research in which experiments are not expected to benefit the subject but are designed to add to the understanding of normal and diseased states, it might be advisable to adopt regulations somewhat similar to those in force in the United States with respect to grants made under the authority of the Department of Health, Education, and Welfare. The testing of new drugs also requires special rules. Actually, the various ethical rules of conduct considered earlier in this article appear to be adequate as they contain sufficient safeguards for the patient or subject.

Peer review is important. It is suggested that involvement of the laity in medical ethics should be kept at the minimum as it is questionable whether the lay public is able to grapple more effectively with the complex moral and scientific judgments about human experimentation. However, the role of the laity may be important in determining whether the conditions of informed and free consent have been met. Review by the researcher's peers and guidelines for obtaining an informed and free consent would seem to be sufficient in the case of clinical research. The review would insure independent determination of the rights and welfare of individuals involved in such clinical studies, the appropriateness of methods used to secure their informed and free consent, and an assessment of the risk-benefit ratio. Peer review can be much more effective than laws and regulations provided precise procedural rules and substantive standards are followed and applied in the review process.

As long as the patient or his representative is capable and under no duress and has consented after being given a fair explanation of the procedures to be followed, a description of possible discomforts and risks, a description of possible benefits, a disclosure of alternative procedures, an offer to answer all inquiries, and a clear enunciation of the patient's freedom to withdraw from the study at any time, there is no reason for invalidating such consent and holding the physician criminally or civilly liable. In conclusion, an effective way to protect the interests of patients or subjects is to make sure that the physician will adjust to the requirements of informed decision making. 
The doctrine of informed consent should not be pushed to such extremes that hospitals will require consent from patients to use their sweat, urine and feces for experimental purposes. Also, there should be flexibility as to the amount of disclosure when therapeutic treatment is involved and full disclosure would be detrimental to the health of the patient. In such a case full disclosure should be made to the patient's relatives or representatives without fear that this contributes a breach of professional secret.

As noted previously, it is often difficult to determine when the physician has a professional duty to inform his patient and when he should obtain an expressed informed consent. Where should the line be drawn between implied consent and the need for express informed consent? Obviously, in the case of a routine visit or medical check-up there is no need for an informed consent. However, consent must exist to protect the physician against a possible charge of assault and battery when examining the patient. In such a case consent is implied in the physician-patient relationship.

The danger in enacting too many laws and regulations is that they will inhibit scientific investigation and bring us back to medieval times when new practices and procedures were abhorred. The best and probably only guarantee of a patient or subject's rights is the integrity of his physician.

On the private law side, the Civil Code of Quebec could be amended in order to contain a special provision dealing with the effect of the victim's consent upon the reparation of his damage in case of infringement of rights that can be waived. The Civil Code or the common law should take consent into consideration when the victim of a delict or quasi delict or of a tort seeks reparation. The doctrine of volenti non fit injuria is not fully adequate.

For instance in Switzerland article 44 of the Code of Obligations states:

Le juge peut réduire les dommages intérêts, ou même n'en point allouer lorsque la partie lésée a consentie à la lésion ou lorsque des faits dont elle est responsable ont contribué à créer le dommage, à l'augmenter, ou qu'ils ont aggravé la situation du débiteur.

This provision could be applied whether the liability of the actor is contractual or delictual. 